\title{
Neuroprotective Strategies for Retinal Ganglion Cell Degeneration: Current Status and Challenges Ahead
}

\author{
Raquel Boia ${ }^{1,2}{ }^{(}$, Noelia Ruzafa $^{3}$, Inês Dinis Aires ${ }^{1,2} \mathbb{D}^{-}$Xandra Pereiro $^{3}$, \\ António Francisco Ambrósio $1,2,4$ (D), Elena Vecino ${ }^{3}$ and Ana Raquel Santiago 1,2,4,*(D) \\ 1 Coimbra Institute for Clinical and Biomedical Research (iCBR), Faculty of Medicine, University of Coimbra, \\ 3000-548 Coimbra, Portugal; raquelfboia@gmail.com (R.B.); inesaires9@gmail.com (I.D.A.); \\ afambrosio@fmed.uc.pt (A.F.A.) \\ 2 Center for Innovative Biomedicine and Biotechnology (CIBB), University of Coimbra, \\ 3000-548 Coimbra, Portugal \\ 3 Department of Cell Biology and Histology, University of the Basque Country UPV/EHU, \\ 48940 Leioa, Vizcaya, Spain; noelia.ruzafa@ehu.eus (N.R.); xandra.pereiro@gmail.com (X.P.); \\ elena.vecino@ehu.eus (E.V.) \\ 4 Association for Innovation and Biomedical Research on Light and Image (AIBILI), \\ 3000-548 Coimbra, Portugal \\ * Correspondence: asantiago@fmed.uc.pt; Tel.: +351-239480226
}

Received: 18 February 2020; Accepted: 20 March 2020; Published: 25 March 2020 updates

\begin{abstract}
The retinal ganglion cells (RGCs) are the output cells of the retina into the brain. In mammals, these cells are not able to regenerate their axons after optic nerve injury, leaving the patients with optic neuropathies with permanent visual loss. An effective RGCs-directed therapy could provide a beneficial effect to prevent the progression of the disease. Axonal injury leads to the functional loss of RGCs and subsequently induces neuronal death, and axonal regeneration would be essential to restore the neuronal connectivity, and to reestablish the function of the visual system. The manipulation of several intrinsic and extrinsic factors has been proposed in order to stimulate axonal regeneration and functional repairing of axonal connections in the visual pathway. However, there is a missing point in the process since, until now, there is no therapeutic strategy directed to promote axonal regeneration of RGCs as a therapeutic approach for optic neuropathies.
\end{abstract}

Keywords: retinal ganglion cells; neurodegeneration; axonal regeneration; neuroprotection; optic neuropathies

\section{Introduction}

The retina is part of the central nervous system (CNS) and is constituted by neurons, glial cells and blood vessels [1]. The neuronal component of the retina is composed by six types of neurons: photoreceptors (rods and cones), bipolar cells, horizontal cells, amacrine cells and retinal ganglion cells (RGCs). Photoreceptors, whose nuclei is located in the outer nuclear layer (ONL), respond to light and make synapses with second-order neurons. The cell bodies of retinal interneurons (horizontal, bipolar and amacrine cells) are located predominately in the inner nuclear layer (INL) and modify and relay the visual information from the photoreceptors to the RGCs that are located in the innermost layer of the retina, the ganglion cell layer (GCL) (Figure 1). RGCs are the output cells of the retina that convey the visual signals to the brain visual targets. The axons of RGCs run initially in the nerve fiber layer (NFL) and converge into the optic disc, cross the lamina cribrosa at the optic nerve head (ONH), and form the optic nerve (Figure 1) [1]. 


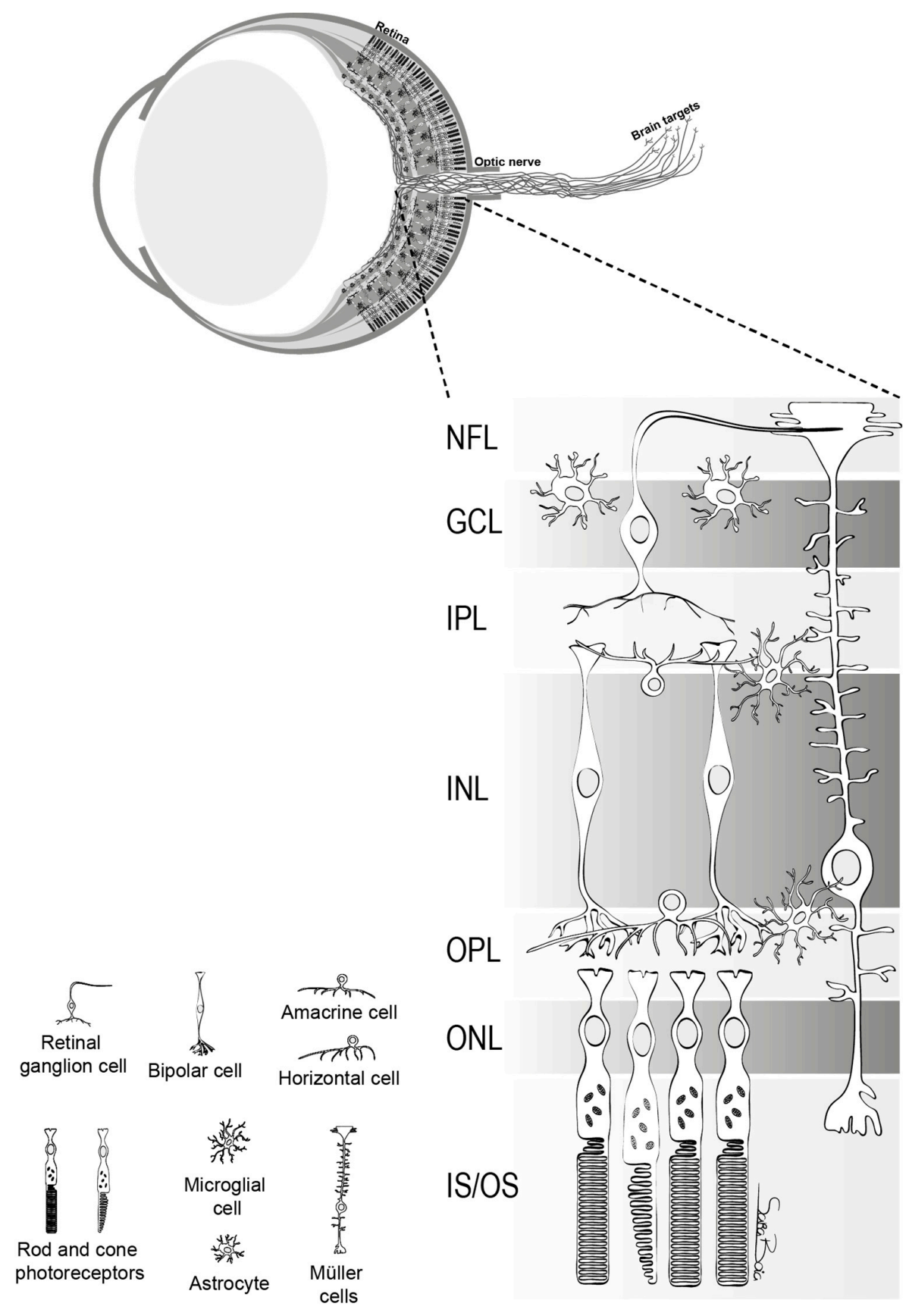

Figure 1. Schematic representation of the neural sensory retina, depicting the organization of the cells into nuclear and plexiform layers. The nuclei of photoreceptors, rods and cones, are located in the outer nuclear layer (ONL) and nuclei of interneurons, amacrine, bipolar and horizontal cells, are located predominately in the inner nuclear layer (INL). The cell bodies of RGCs are in the ganglion cell layer (GCL), and their axons run in the nerve fiber layer (NFL). There are two types of macroglia: Müller cells that span vertically the entire retina and astrocytes that are present in the GCL. Microglial cells are localized predominately in the inner retina and in the outer plexiform layer (OPL). IPL: inner plexiform layer; IS/OS: inner and outer segments of photoreceptors.

Optic neuropathies comprise a group of ocular diseases, like glaucoma (the most common), anterior ischemic optic neuropathy and retinal ischemia, in which RGCs are the main affected cells [2]. Blindness secondary to optic neuropathies is irreversible since RGCs lack the capacity for self-renewal and have a limited ability for self-repair [3]. The exact mechanism that leads to RGC death and degeneration is still unknown, but axonal injury has been proposed as an early event that culminates 
in apoptotic death of RGCs [4]. This paper reviews the events that contribute to axonal degeneration and death of RGCs and also the neuroprotective strategies with potential to circumvent this problem.

\section{Obstacles to RGC Survival and Regeneration upon Injury: Insights from Development to Disease Models}

During development, RGCs extend their axons to synapse in target areas of the brain (reviewed in [5]). After birth, there is a peak in cell death that in rodents occurs between postnatal days 2 and 5 (PND 2-5), ensuring that only cells that reached their targets survive (reviewed in [6]). The ability of RGCs to extend their axons decreases with age and the capacity to regenerate their axons is lost early in development [7]. In fact, cultures of RGCs (Figure 2) prepared at both embryonic day 20 (ED 20) or PND 8 extend their axons with similar calibers; however, after 3 days in culture, ED 20 RGCs extend their axons further and faster than cells isolated at PND 8. The exposure of these cells to conditioned media of superior colliculus cells further potentiates axonal growth of ED 20 RGCs without interfering with PND 8 RGCs, demonstrating that the loss of ability of RGCs axon growth is mediated by retinal maturation [7]. The reason behind the lost in the intrinsic ability of RGCs to regenerate upon injury has been extensively explored. Several players, including cyclic adenosine monophosphate (cAMP), phosphatase and tensin homologue (PTEN)/mammalian target of rapamycin (mTOR) and Krüppel-like family (KLF) transcript factors are implicated in the transition from the rapid axon growth of immature neurons into the poor axon growth of mature neurons in the CNS.

A

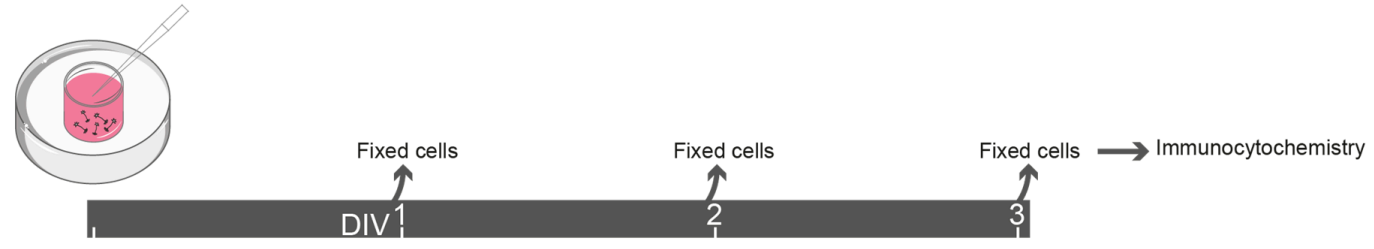

Cell plated

B

DIV

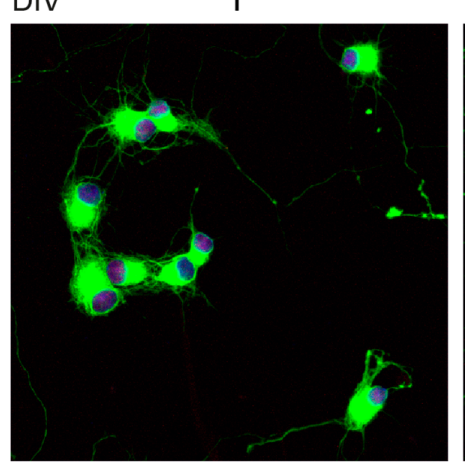

$\beta-$ III Tubulin + Brn3a + DAPI
2

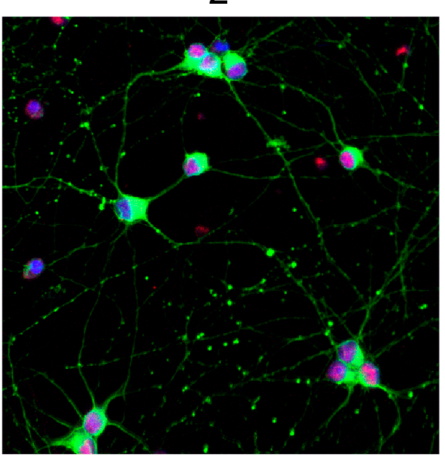

3

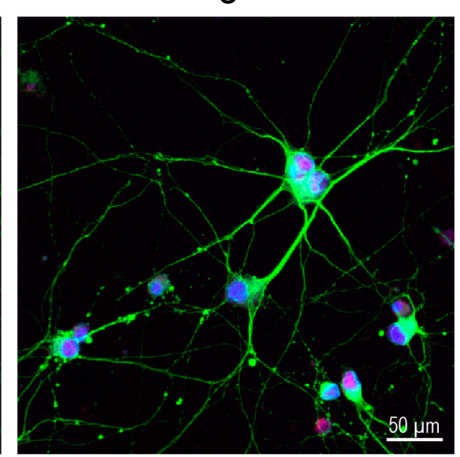

Figure 2. Neurite growth of RGCs in culture. (A) Schematic representation of the experimental design. Retinas were dissected from Wistar rats at PND 5 and nearly pure RGC cultures ( 93\% purity assessed with anti-RBPMS antibody; Abcam, Cat. \# ab194213, 1:500) were obtained by sequential immunopanning, as previously described [8,9]. RGCs were cultured for 1 day in vitro (DIV1), DIV2 and DIV3, followed by fixation in paraformaldehyde and processed for immunocytochemistry. (B) RGCs were identified by immunolabeling for Brn3a (red, Millipore, Cat. \# MAB1585, 1:500), a transcription factor expressed only by these cells in the retina. The neurites, labelled with an antibody that recognizes $\beta$-tubulin III (green, BioLegend, Cat. \# 802001; 1:1000), extended during the period in culture. Nuclei were stained with DAPI (blue). 
cAMP plays an important role in neuronal survival and axon growth and guidance [10]. For example, in the goldfish, the injection of an analogue of cAMP is able to enhance axonal regeneration upon optic nerve crush (ONC) [11]. Moreover, PTEN/mTOR pathway has been implicated in the failure of RGCs axons to regenerate. The deletion of PTEN in RGCs leads to the activation of phosphoinositide 3-kinases (PI3K)/mTOR pathway, increases neuronal survival and promotes robust axon regeneration after optic nerve injury $[12,13]$. Moreover, it has been reported a coordinated regulation of neurite growth by KLF transcription factors. During development, at least two growth-enhancing KLFs (KLF6 and 7) are down-regulated, and at least two growth-suppressive KLFs (KLF4 and 9) are upregulated [14]. The profile of gene expression from ED 17 through PND 21 RGCs identified the zinc finger transcription factor KLF4 as the most effective suppressor of neurite outgrowth [14]. Indeed, the KLF4 overexpression in ED 20 RGCs reduces their ability to extend axons and, on the other hand, KLF4 knockout enhances axon growth ability by PND 12 RGCs [14]. This decline in the ability of postnatal RGCs to grow axons is associated with KLF-regulated changes in axonal growth cone morphology and protrusive dynamics [15]. The knockout of KLF4 during development increases the regenerative potential of RGCs upon ONC at adulthood [14]. Amacrine cells have been implicated in the process of losing intrinsic growth capability of RGCs [7]. In fact, zinc $\left(\mathrm{Zn}^{2+}\right)$ increases in amacrine cell processes upon optic nerve injury and is transferred to RGCs via vesicular release [16]. The chelation of $\mathrm{Zn}^{2+}$ improves cell survival and axon regeneration [16], raising the possibility that the dysregulation of mobile $\mathrm{Zn}^{2+}$ levels is responsible for the loss of axonal growth.

Other transcription factors have been studied for their role in axon growth and regeneration (reviewed in [17]). The tumor suppressor p53 plays a central role in the regulation apoptosis in RGCs. The overstimulation of N-methyl-D-aspartate (NMDA) receptor activates a p53-dependent pathway of cell death [18]. The involvement of p53 in neurite outgrowth and axon regeneration has been explored in CNS injury [19]. However, the deletion of p53 in RGCs fails to promote axonal regeneration, despite the increase in RGC survival upon ONC [12], confirming the hypothesis that inducing neuronal survival is not enough to allow axonal regeneration. The activation of $\mathrm{p} 53$ has been implicated in the transcription of several factors responsible for apoptosis, as pro-apoptotic BAX or anti-apoptotic Bcl-2 proteins (reviewed in [20]). It was shown that there is an up-regulation of BAX expression after ONC injury [21], as well as after ischemic retinal damage [22]. BAX deficiency completely prevents RGCs death in a glaucoma animal model [23]. However, deficient BAX expression in not sufficient to hinder axonal degeneration even without RGC death, reinforcing the idea that axon degeneration is not a consequence of RGC death [23]. A down-regulation of the anti-apoptotic protein Bcl-2 was observed in RGCs in the GCL when the onset of regenerative failure of RGCs occurs [24]. Elevating the expression of Bcl-2 maintains neuronal survival even after withdrawing of all trophic factors in cultures of RGCs [3]. However, Bcl-2-overexpressing RGCs fail to elaborate axons or dendrites, unless axon growth-inducing signals are present, clearly demonstrating that axon growth is not a default function of a surviving neuron, but must be specifically signaled [3]. These evidences clearly demonstrate that manipulation of some intrinsic factors could have beneficial effects, not only in the prevention of RGC death but also in promoting axon regeneration upon injury. In the peripheral nervous system (PNS) the injured neurons are able to regenerate, which does not happen in the CNS. However, the observation that CNS neurons, including RGCs, regrow into peripheral nerve grafts $[25,26]$, confirms the possibility that extrinsic factors also have a preponderant role in limiting axonal repair.

Glial scar and myelin that compose the environment of optic nerve particularly at the site of injury inhibit the axonal regeneration (reviewed in [27]). Semaphorin-3 is expressed in the core of the glial scar upon CNS injury [28] and limits regenerating neurons crossing semaphorin-3A (Sema3A)-expressing regions [29]. This raises the hypothesis that semaphorins may have a potential role in the glia inhibiting effect of axonal regeneration. Semaphorins have an important function in neuronal polarity and axonal guidance during RGC development or injury [30]. Sema3A is one of the extracellular factors that is involved in regulating RGC polarity [31,32]. At PND 14, when all RGCs axons reached their targets [33], 
Sema3A is elevated [34], and increased expression of Sema3A results in strong axonal inhibition in optic nerve injury model [35]. In line with these findings and corroborating the role of semaphorin in axonal growth, the intravitreous injection of antibodies against the Sema3A-derived peptide to neutralize the function of Sema3A, caused a marked inhibition of RGC loss in an animal model of complete axotomy of the rat optic nerve [36]. Sema5A is a semaphorin produced by oligodendrocytes that also contributes to the inhibitory environment of the injured optic nerve, heralded by the observation that RGC axonal growth increases when blocking Sema5A [37]. It has been demonstrated that myelin proteins inhibit axonal regeneration in adult neurons. Following an insult, nonspecific T cells accumulate at the lesion site on optic nerve $[38,39]$. Immunization with $\mathrm{T}$ cells specifically against myelin proteins (copolymer-1, Cop-1) reduces the post-traumatic neuronal loss after ONC [38,39]. Moreover, it has been shown to be an effective therapy for glutamate-induced toxicity in mice and in a rat model of chronically high intraocular pressure (IOP) [40]. Although these studies were only focused on the survival of RGCs, some years after the authors demonstrated that Cop-1 treatment confer functional protection to RGCs [41]. Other studies led to the identification of several myelin-associated inhibitors of axon growth. Nogo-A is one of the most potent oligodendrocyte-derived inhibitors for axonal regrowth in the injured adult CNS [42,43] that is also expressed by RGCs [44]. In cases of optic nerve injury Nogo-A is upregulated [45], although the overexpression or down-regulation of Nogo-A does not impact the survival of injured RGCs. However, the neuronal knockout of Nogo-A diminishes the axonal growth response, demonstrating a role for Nogo-A in RGCs growth after injury [45]. On the other hand, axonal sprouting is increased in the optic nerves of oligodendrocyte-specific Nogo-A knockout mice [46], demonstrating that the inactivation of Nogo-A in oligodendrocytes appears to be a good strategy to promote axonal regeneration. Moreover, it was reported that neutralizing Nogo-A has beneficial effects on visual recovery and plasticity after retinal injury [47]. Moreover, myelin-associated glycoprotein (MAG) is a component of the myelin-derived inhibition of nerve regeneration [48]. It seems that a possible mechanism underlying synapse degeneration and RGCs death in glaucoma is mediated by Nogo-A [49]. The antagonism of Nogo receptor $(\mathrm{NgR})$ reduces RGCs loss and attenuates synaptic degeneration [50] and the knockout of $\mathrm{NgR}$ is effective in enhancing axonal regeneration after ONC [51].

The failure to regenerate has also been attributed to an environment poor in growth-promoting trophic factors. In fact, the importance of trophic factors in promoting viability and axonal regeneration of RGCs has long been recognized [51]. A great variety of neurotrophins were found to induce axon growth, which include nerve growth factor (NGF), brain-derived neurotrophic factor (BDNF) and ciliary neurotrophic factor (CNTF). BDNF plays an important role in RGCs neuroprotection since the levels of BDNF are increased in response to injury [52,53]. BDNF is also highly expressed in the superior colliculus $[54,55]$ and it is retrogradely transported to the retina. However, displaced amacrine cells in the GCL are the main source of BDNF to RGCs [56]. The application of BDNF to the superior colliculus reduces RGC death during development [57]. Moreover, several studies demonstrated that administration of BDNF into the eye increases the survival of RGCs upon injury, and ameliorate their function [58-64].

The survival of RGCs is increased by co-administration of BDNF and CNTF soon after optic nerve injury [65]. Moreover, RGCs extend their axons in response to BDNF and CNTF, but both together induce more axon growth than either alone [3], raising the hypothesis that different factors may be responsible for different facets of axon growth. However, neurotrophins fail to induce axon growth alone. For instance, RGCs fail to survive in the presence of such trophic factors as BDNF or CNTF unless their cAMP levels are elevated [66]. CNTF overexpression promotes long-term survival and regeneration of injured adult RGCs [67]. It was described that exogenously applied CNTF stimulates RGCs partially indirectly via a mechanism that depends on astrocyte-derived CNTF [68]. The NGF has also an important role in promoting RGCs survival, being the Schwann cells the main source of this factor [69]. Intraocular injection of NGF has been previously shown to promote RGC survival [70]. 
Studying the mechanisms of glaucomatous damage has been a great opportunity to unravel the signaling pathways involved in RGC axonal degeneration and growth. Elevated IOP is the main risk factor of glaucoma and, together with other factors, it has been implicated in RGC degeneration and death [71]. Several in vitro models have been developed [72] and allowed the demonstration that there are pressure-dependent changes in the length of axons and neurites of RGCs [73]. When cultures of RGCs are challenged with elevated pressure there is a severe impact in axon length and in the total neurite length, with a weakened neurite extension (Figure 3), without interfering with cell body area [73]. In glaucoma, the increased IOP perturbs anterograde and retrograde axonal transports that lead to deprivation of RGCs of neurotrophic factors produced by brain targets [74]. In fact, the retrograde transport of BDNF is impaired after IOP elevation, and this may contribute to RGC loss $[75,76]$.

Recently, it was reported that intravitreal injections of BDNF leads to an increase in the levels of synaptic proteins between RGCs and bipolar cells in the IPL, meaning that this could have a beneficial effect in the function of RGCs [77].

A

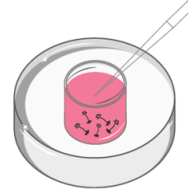

Cell plated

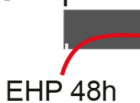

C

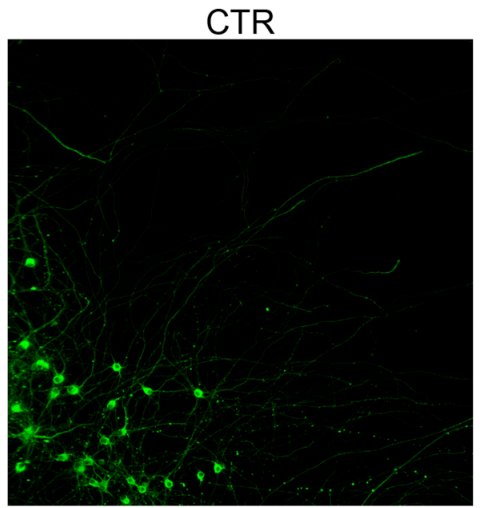
$\beta$-III Tubulin

D

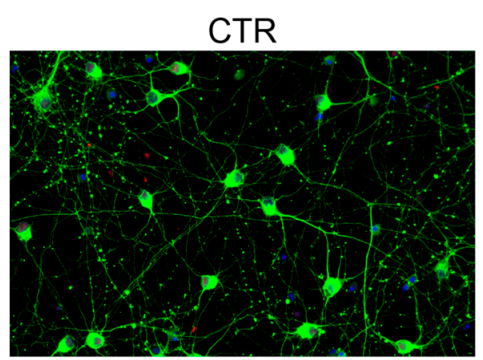

$\beta-I I I$ Tubulin + Brn3a + DAPI

EHP 24h
B

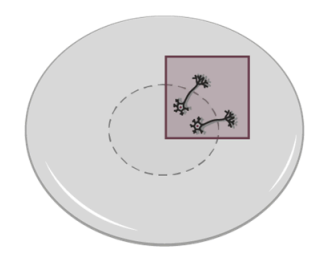

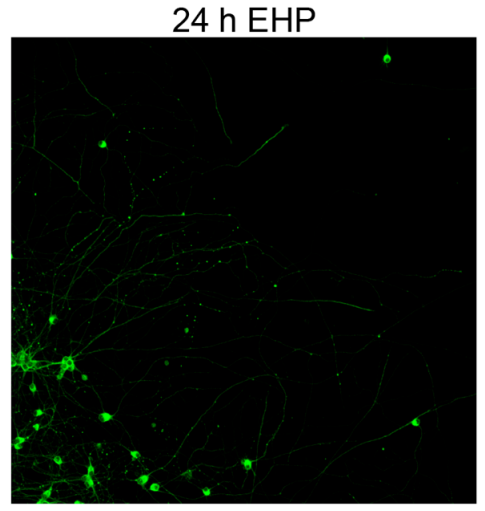

$24 \mathrm{~h}$ EHP
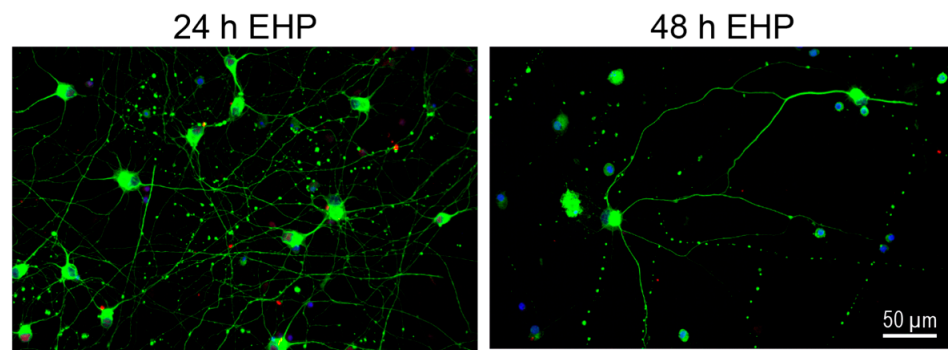

$48 \mathrm{~h}$ EHP

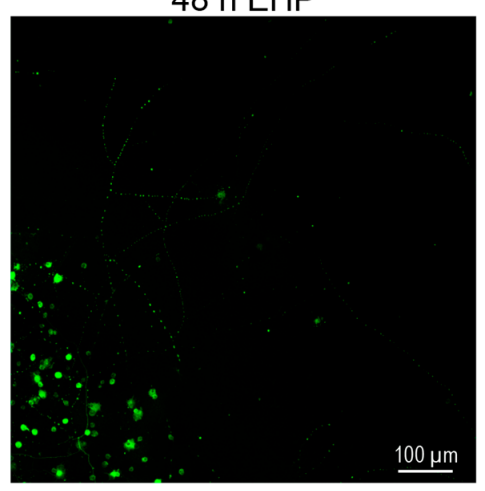

Figure 3. Elevated hydrostatic pressure (EHP) impacts neurite growth of RGCs. (A) Schematic representation of the experimental design. RGCs were purified from Wistar rats at PND 5 by sequential 
immunopanning, as previously described [8,9] and were cultured for DIV2. RGCs were challenged with EHP (+70 mmHg above atmospheric pressure) [78,79]) for $24 \mathrm{~h}$ and $48 \mathrm{~h}$ and then processed for immunocytochemistry as described in the legend of Figure 2. (C) RGCs were plated in a coverslip with a cloning cylinder and neurite extension was observed beyond the limit established by the cylinder (B, grey dashed circle). Exposure to EHP decreased the length of the neurites when compared with the control (CTR) condition (normal pressure). (D) Higher magnification. This effect on the neurites of RGCs is dependent on the duration of the exposure to EHP.

\section{Potential Therapeutic Targets Aiming RGC Neuroprotection}

Several therapeutic strategies have been proposed in order to protect RGCs and restore visual function (Figure 4).

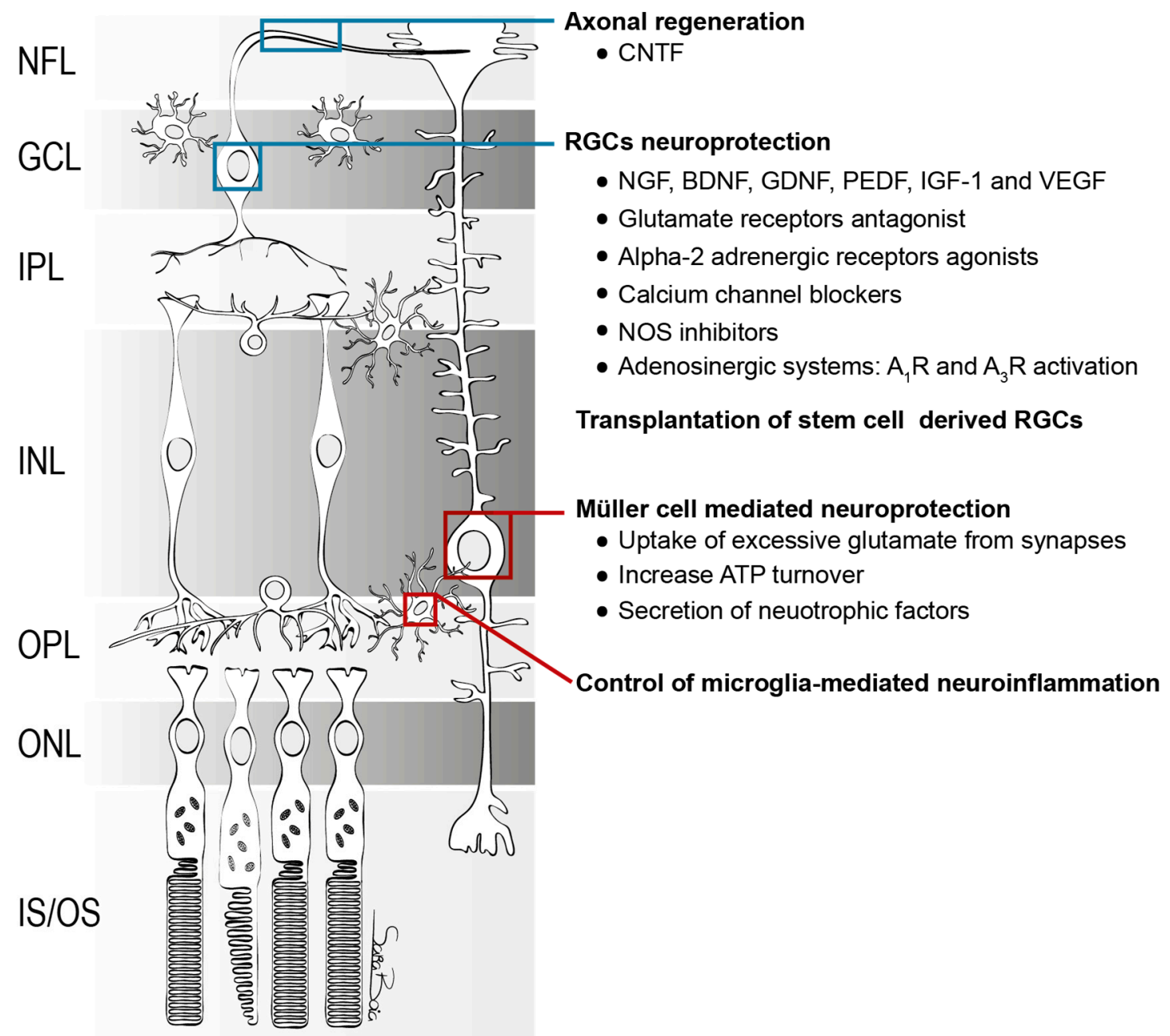

Figure 4. Schematic representation of the main strategies for RGC neuroprotection. Blue squares represent the therapies directed to RGCs and red squares represents the undirected therapies that culminates in RGCs neuroprotection.

\subsection{Neuroprotective Therapies}

\subsubsection{Neurotrophic Factors}

Neurotrophic factors are a family of growth factors that regulate the survival, development and differentiation of neurons. Neurotrophic factors generally include the neurotrophin family: NGF, BDNF, neurotrophin-3 (NT-3) and neurotrophin-4/5 (NT-4/5); the glial cell-line derived neurotrophic factor (GDNF) family: GDNF, neurturin (NRTN), artemin (ARTN), and persephin (PSPN); and CNTF $[80,81]$. 
It was reported that most of these neurotrophic factors, which can be produced by glial cells, increase RGC survival in different experimental models of injury $[53,82-88]$. Neurotrophic factors bind to different receptors and transduce diverse intracellular signals. Usually, neurotrophic factors bind to the high affinity receptor tyrosine kinase (Trk family) that promote cell survival. For instance, NGF binds to TrkA, BDNF and NT-4 to TrkB, and NT-3 binds to TrkC. However, they can also bind to the low affinity neurotrophin receptor p75 (p75NTR) and induce programmed cell death. These opposing effects of neurotrophic factors are important for regulating RGCs development $[80,81]$. The distribution of neurotrophic factors and their receptors in the mammalian retina has been studied in detail in physiology as well as in pathological conditions [52,53]. Of interest, especially when using in vitro models to study these mechanisms, the expression of neurotrophic factors and their receptors is preserved in glial cells and in RGCs even when in culture for 6 days [86] and the factors secreted by Müller cells offer protection to cultured RGCs [89].

Nerve Growth Factor (NGF)

NGF is an important growth factor affecting the survival of nerve cells and their deprivation can lead to apoptosis [90,91]. NGF is produced and utilized by RGCs [92] and protects these cells after injury [93-95]. Furthermore, NGF treatments reduced the progressive loss of RGCs in a glaucoma model [93]. In addition, in patients with glaucoma, NGF eye drops resulted in an improvement of the INL function, neural conduction, visual field, optic nerve function, contrast sensitivity, and visual acuity [96]. However, further studies are required to confirm the therapeutic efficacy of NGF.

\section{Brain-Derived Neurotrophic Factor (BDNF)}

BDNF is widely expressed throughout the CNS. RGCs express BDNF and its high affinity receptor TrkB [97]. As mentioned above, it is a powerful neuroprotective agent that promotes the survival and regrowth of RGCs $[61,62,98]$. The exposure to NMDA induces an increase in BDNF expression in RGCs in the first hours, suggesting that it is an endogenous neuroprotective response of RGCs. However, this effect is not sustained over time, maybe because the cells cannot maintain the synthesis of BDNF or because the activation of the apoptotic mechanism inhibits BDNF synthesis [52,84]. It has been speculated that the therapeutic properties of different neuroprotective agents in promoting RGC survival are related to the induction of retinal BDNF expression $[99,100]$. Consistently, BDNF levels are reduced in the serum and tears of glaucoma patients, suggesting that deficits in this neurotrophin may participate in RGC death in glaucoma and that BDNF may be a biomarker for glaucoma $[101,102]$.

\section{Glial Cell Line-Derived Neurotrophic Factor (GDNF)}

GDNF is secreted by glial cells and binds to the GDNF- $\alpha$ receptor and to the receptor tyrosine kinase in RGCs [103]. GDNF promotes the survival of RGCs after injury [104-106]. Moreover, GDNF treatments, specifically intravitreal injection of microspheres containing GDNF, protect RGCs in glaucoma animal models $[107,108]$. This neuroprotective property of GDNF may be orchestrated by Müller cells. GDNF upregulates the glutamate/aspartate transporter (GLAST) in Müller cells enhancing glutamate uptake that may indirectly protect RGCs [109]. Another possible mechanism of action could be through osteopontin since activation of Müller cells by GDNF was shown to induce the secretion of osteopontin [110]. Thus, GDNF holds strong therapeutic potential for retinal neurodegenerative diseases.

\section{Ciliary Neurotrophic Factor (CNTF)}

CNTF belongs to the interleukin-6 (IL-6) family of cytokines, binds to CNTF receptors (CNTFR) and exerts robust neuroprotection in neurons $[81,111]$. In the retina, CNTF is expressed by various cell types, particularly by Müller cells [112]. Its neuroprotective effects are mediated especially by these glial cells that directly respond to CNTF by releasing other neurotrophic factors such as basic fibroblast growth factor (bFGF) [113]. The neurotrophic properties of CNTF were tested in several animal models 
of glaucoma and in ischemic optic neuropathy [60,114-116]. CNTF is also capable of stimulating axonal regeneration [117], which may be mediated by astrocytes [118]. Notably, the concentration of CNTF in the aqueous humor, lacrimal fluid and blood serum is decreased in patients with glaucoma [119]. The results of CNTF in neuroprotection and regeneration suggest a potential for clinical use; however, the pharmacology and administration of CNTF must be optimized.

\section{Other Trophic Factors}

Other trophic factors have been described to promote RGCs survival. Pigment epithelium derived factor (PEDF) reduces RGC loss in a mouse model of glaucoma [120] and insulin-like growth factor-1 (IGF-1) also protects RGCs from different injuries [121,122]. Despite the role of vascular endothelial growth factor A (VEGF-A) in neovascularization, VEGF is also a neuronal trophic factor that may play a role in RGC neuroprotection. Indeed, it reduces RGC apoptosis in models of glaucoma and anti-VEGF therapies exacerbate neuronal cell death [123-126].

\subsubsection{Glutamate Receptors Antagonists}

Despite being the major excitatory neurotransmitter in the retina and involved in the vertical pathway of information [1], excessive glutamate levels have detrimental effects on RGCs [127], a term described as glutamate excitotoxicity [128], due to the activation of a complex apoptotic cascades [128,129]. The fact that intraocular glutamate levels are increased in glaucoma patients $[130,131]$ raised the hypothesis that the blockade of glutamate receptors could be a valuable strategy for RGC neuroprotection, at least for glaucoma. MK801 (dizocilpine maleate) is a potent glutamate receptor antagonist and is a neuroprotective agent of RGCs [132,133], although it could also be neurotoxic [134]. In preclinical studies memantine, a NMDA receptor antagonist, affords robust neuroprotection of RGCs against glutamate toxicity [129,135]. However, memantine had limited efficacy in glaucoma patients $[136,137]$. More studies are required to clearly evaluate these and other glutamate antagonists as effective neuroprotective therapies for RGCs.

\subsubsection{Alpha-2 Adrenergic Receptors Agonists}

The presence of alpha-adrenergic receptors in the RGCs has been demonstrated [138]. Additionally, the activation of alpha-2 adrenergic receptors by agonists such as brimonidine has been shown to enhance survival of RGCs after different types of injuries, namely in glaucoma [138-141], ONC [142] and ischemia [143]. Brimonidine can confer protection by reducing the accumulation of extracellular glutamate and by blocking NMDA receptors, independently of the IOP-lowering mechanisms [139,140,142,144]. Several pre-clinical and clinical studies were conducted [139,145-148] to assess the protective properties of brimonidine.

\subsubsection{Calcium Channel Blockers}

Calcium channel blockers may protect RGCs by preventing cell death mediated by calcium influx secondary to NMDA receptor overactivation and local ischemia $[149,150]$. Different calcium channel blockers attenuate injury to RGCs [151] and increase the viability of immunopurified RGCs cultures [152]. A randomized clinical trial analyzed the effects of the treatment with nilvadipine, a calcium channel blocker, on visual field performance and ocular circulation in patients with open-angle glaucoma. Nilvadipine slowed visual field progression, maintained the optic disc rim, and increased the posterior choroidal circulation [153]. Although these findings look promising, more studies on the distribution and pharmacology of the several types of calcium channels could help clarifying their therapeutic value [154]. 


\subsubsection{Antioxidants}

Oxidative stress occurs when concentrations of reactive oxygen species (ROS) rise above physiological range, and it has been indicated as a potential cause of glaucomatous neurodegeneration [155]. Thus, inhibition of ROS may enhance RGC survival [156-158]. Coenzyme Q10, cofactor of the electron transport chain that inhibits the generation of ROS, protects retinal neurons from damage [159-161]. Moreover, improvement in visual acuity has also been reported in patients with optic neuropathy after treatment with Q10 [162].

Glutathione (GSH) is decreased in glaucoma patients, suggesting a general compromise of the antioxidative defense [163]. The treatment with vitamin E can ameliorate the decrease in the levels of retinal GSH [164,165]. Consequently, vitamin E-deficient diet is associated with an increase of RGC death related to an increase in lipid peroxidation [166]. Moreover, methane increases the activity of several antioxidant enzymes like superoxide dismutase (SOD), catalase (CAT), glutathione peroxidase (GPx), and the expression of anti-apoptotic genes, which culminate in reduced RGC loss [167]. Overexpression of frataxin induces up-regulation of antioxidant enzymes (such as SOD2, CAT, GPx) and increases RGC survival [168]. Other agents, like crocin, increase the levels of GSH and SOD activity, decreasing ROS and promoting RGC survival [169]. Generally, an increase of SOD and alpha-lipoic acid protects RGCs against oxidative stress damage [170,171]. Therefore, evidence demonstrate that antioxidants may be beneficial for neuroprotection of RGCs [148], but further studies are required to investigate their full potential.

\subsubsection{Nitric Oxide Synthase Inhibitors}

The levels of nitric oxide (NO) are increased in experimental glaucoma, and evidence shows that NO can result in RGCs degeneration [172-175]. Moreover, increased expression of nitric oxide synthase (NOS) was detected in different models of RGCs injury [175-177]. Additionally, in glaucoma patients the astrocytes of $\mathrm{ONH}$ become reactive and may produce high amounts of NO causing neurotoxicity to the axons of RGCs [178,179]. This has raised the hypothesis that the inhibition of NOS, in particular inducible NOS (iNOS), could be neuroprotective by delaying RGCs degeneration [180,181]. However, other studies did not identify a relationship between iNOS and RGCs neurodegeneration [182,183]. More studies are necessary to clarify the role of NOS inhibitors in RGCs protection, helping to clarify this "apparent" discrepancy.

\subsubsection{Adenosinergic System}

Adenosine can exert both neuroprotective and neurodegenerative actions acting through four types of receptors: $A_{1}, A_{2 A}, A_{2 B}$ and $A_{3}$. Adenosine acting on adenosine $A_{1}$ receptor $\left(A_{1} R\right)$ protects cultured retinal neurons from NMDA-induced cell death [184] by blocking calcium channels in RGCs [185], suggesting that agents directed to $A_{1} R$ could be a good therapeutic strategy. Indeed, the activation of $A_{1} R$ is neuroprotective against injury induced by ischemia-reperfusion [186], and $\mathrm{N}(6)$-cyclohexyl-adenosine (CHA), an agonist of $A_{1} R$, increases RGCs survival mediating the trophic effect of IL-6 [187]. In fact, IL-6 is an interesting cytokine that has been demonstrated to promote RGCs survival [188,189], probably by the modulation of BDNF synthesis [190]. Adenosine $A_{3}$ receptor $\left(\mathrm{A}_{3} \mathrm{R}\right)$ has also been evaluated as a therapeutic target [191]. RGCs are endowed with $\mathrm{A}_{3} \mathrm{R}$ [192], and its activation protects RGCs from cell death induced by P2X7 receptor agonist $[193,194]$, possibly by limiting the rise in intracellular calcium [195]. Activation of $\mathrm{A}_{3} \mathrm{R}$ promotes RGCs neurite outgrowth and neurite regeneration in an animal model of ONC [196]. Moreover, the activation of $A_{3} R$ was also demonstrated to afford protection to the retina from excitotoxic-induced cell death, retinal ischemia-reperfusion injury and damage induced by partial optic nerve transection [197]. 


\subsection{Cell-Based Therapies}

Beyond neuroprotection, cell replacement may have potential as a strategy for the treatment of optic neuropathies. Replacing the diseased or degenerated cells by stem cell-derived RGCs should provide effective therapeutic treatment in the near future. However, complex circuitry in the retina makes cell replacement challenging and difficult for functional repair [198].

Stem cells are functionally undifferentiated and immature cells of a complex nature. These cells are capable of differentiating into different cell types, indicating that they have the potential to repair tissue and restore function after lesion. Due to this potential, it is believed that stem cells may be able to either replace or repair damaged cells in the retina [199-201].

In the past decade, the capacity to generate retinal cells from pluripotent stem cells using three-dimensional organoid cultures has become well established [202-204]. However, while corneal transplantation is commonly performed with excellent results, many obstacles must be surpassed before retinal transplants can become clinically useful. The major problems are the production of appropriate transplants, functional integration in situ and the survival of the stem cell-derived RGCs.

Various types of stem cells were assessed for retinal differentiation and transplantation such as human embryonic stem cells, induced pluripotent stem cells, isolated retinal stem cells and also from adult stem cells, in particular neural stem cells, mesenchymal stem cells (MSCs) derived from bone marrow, adipose tissues and dental pulp [205].

Various methods to assess the ability of RGCs to survive and integrate with host tissue have been proposed [206,207]. Transplanted RGCs by intravitreal injection acquired the normal morphology of endogenous RGCs, responded to light, and established synaptic contacts with the lateral geniculate nucleus and the superior colliculus [208-210]. These examples show that RGC transplantation is possible, although not very efficient, but further studies will certainly guarantee that transplantation of cells to the retina may become a strategy.

MSCs have been widely demonstrated to afford neuroprotective, immunomodulatory and antioxidant properties, making them a promising strategy for the treatment of neurodegenerative diseases. These cells secrete neurotrophic factors like NGF accelerating the survival of neural cells [211]. The protective properties of MSCs have also been also documented in an animal model of glaucoma and in an animal model of optic nerve injury $[212,213]$. The protective properties of MSCs extend beyond the cells. Recently, the extracellular vesicles derived by these cells were demonstrated to promote RGCs neuroprotection in rodent models of glaucoma $[213,214]$.

\subsection{Glia-Mediated Neuroprotection}

The term neuroinflammation comprises a number of events that affects the CNS. In other words, every time the CNS is faced with infectious agents, traumatic injuries or other unknown elements that might cause a disruption of its homeostasis, it will protect itself by the initiation of inflammatory signaling cascades in order to eliminate the pathological factor [215]. Although the main actors in this scenario are astrocytes and microglia [216,217], in the retina, Müller cells can also be activated and get involved in the production of inflammatory cytokines and chemokines, which maintain and enhance the inflammatory condition participating in the progression of several diseases.

Microglial cells have long been recognized as crucial players in the maintenance of retinal homeostasis. During development, microglial cells are involved in synaptic pruning and in retinal wiring [218] and throughout the life of the organism these cells screen the parenchyma searching for alterations in the environment, including cell interactions and external threats $[219,220]$. In pathological conditions, microglia have been shown to interfere with neural and glial cell function contributing to retinal degeneration and RGC loss [221]. Indeed, several reports show that abnormally responsive microglia can directly reduce the survival of RGCs. For example, even though microglial cells are not endowed with NMDA receptors, upon intravitreal NMDA injection, these cells detect the alterations in calcium and adenosine triphosphate (ATP) signaling in other retinal cells, including RGCs, by increasing the inflammatory response [222]. Interestingly, the report that isolated RGCs are resistant to 
NMDA excitotoxicity [223], while in the retina NMDA exposure leads to RGCs degeneration triggered by increased production of tumor necrosis factor (TNF) and abnormal behavior of microglial cells [222] is another evidence of the role of microglial cells shaping RGCs degeneration.

The pivotal role of microglia in RGCs degeneration has been mostly explored in glaucoma. Historically, reactive microglial cells have been associated with human glaucomatous ONH lesion, mainly by their spatial distribution along the damaged fibers and expression of activation markers as well as pro-inflammatory mediators [224,225]. Indeed, enlarged reactive microglial cells were found in the retina of human post-mortem donors with glaucoma manifestations [224]. Nevertheless, this finding may raise the question of whether microgliosis might be a cause or a consequence of the retinal degeneration. This question was very elegantly addressed using the DBA/2J mouse model of glaucoma when microglia activation in the $\mathrm{ONH}$ was visualized before the detection of RGC loss [226,227]. Furthermore, microglial cell response initiates in the unmyelinated region of the ONH and further develops along the retina, correlating with the progression of the neurodegenerative process [227]. In accordance with these findings, microglia reactivity was shown to impact RGCs survival in different experimental models of glaucoma $[78,79,228]$. Altered ROS signalling has been associated with glaucomatous damage both in animal models and in human glaucoma [179,229], and reactive microglial cells may be the main cellular source [79]. In a model of induced ocular hypertension (OHT), microglia were shown to be reactive as detected by the increased expression of translocator protein (TSPO), major histocompatibility complex class II (MHC-II) and pro-inflammatory mediators in the retina early after OHT induction [230]. Even when exposed to elevated hydrostatic pressure (EHP) an in vitro model of elevated IOP, microglia become reactive, release pro-inflammatory mediators and increase ATP and adenosine secretion [78,231]. Alterations in ATP levels are determinant to propagate microglial cell response by acting as a "call for action" [232]. In addition, adenosine mainly acting through the activation of $A_{2 A}$ receptor $\left(A_{2 A} R\right)$ may propel microglia deleterious response overtime [233]. The $A_{2 A} R$ has been described to control microglia reactivity. Its expression increases in microglia in models of glaucoma [78,79], and $A_{2 A} R$ antagonists were shown to confer protection to retinal neurons, including RGCs, through the control of microglia reactivity $[78,79,228]$. Caffeine, a non-selective adenosine antagonist, also protects RGCs by hampering microglial cell response and controlling the neuroinflammatory environment in models of transient retinal ischemia and ocular hypertension [230,234,235]. KW6002, another $A_{2 A} R$ antagonist with good oral bioavailability, confers protection to the retina, including RGCs, through the control of microglia-mediated neuroinflammation [234]. Recently, the potential of $A_{2 A} R$ antagonists was further confirmed as a strategy for the human retina [78]. By using human retinal organotypic cultures, the $\mathrm{A}_{2 \mathrm{~A}} \mathrm{R}$ antagonist was able to reduce microglia alterations and the production of ROS, suggesting that microglia-mediated inflammation in the human retina also involves $A_{2 A} R$ [78]. The neutralization of the actions of TNF and interleukin-1 $\beta$ (IL-1 $\beta$ ) in the retinal organotypic cultures was able to prevent the loss of RGCs triggered by EHP, reinforcing the role of retinal inflammation in neurodegeneration in glaucoma [79]. The central role of microglia causing RGCs loss was further demonstrated with a strategy to deplete microglia from primary retinal cultures following exposure to EHP [78]. In such case, the effect of EHP on cell death was abrogated, showing that microglia are indeed the main triggers and propellants of neuroinflammation-mediated glaucomatous damage [78].

The secretion of TNF by microglial cells was shown to contribute to RGC degeneration as its receptor is highly increased in glaucoma in RGCs, astrocytes, microglia and Müller cells, triggering a cascade of events that culminates in RGC demise $[236,237]$. Indeed, simple experiments neutralizing the actions of TNF were able to restore axon function and decrease the loss of RGCs in glaucoma [238].

Recently it has been shown that chronic OHT promotes the expression of P2X7 receptor in the retina leading to the activation of NLRP3 (NOD-, LRR- and pyrin domain-containing protein 3) inflammasome [239]. The activation of P2X7R-dependent NLRP3 inflammasome in microglia increases the production of pro-inflammatory cytokines and caspase activation that leads to RGC death [239]. In accordance with the role of purine receptors in microglia reactivity, the inhibition of P2X7 receptor in 
microglial cells confers protection to RGCs in vitro upon exposure to conditioned media from microglia exposed to BzATP by decreasing NLRP3 inflammasome activation [239]. Furthermore, in a model of OHT the oral administration of a saffron extract reduced retinal microglia inflammation and the loss of RGCs, while decreasing the expression of the adenosine diphosphate P2Y12 receptor [240].

Microglial cells also modulate retinal cell function by expressing complement molecules. In fact, in human and experimental glaucoma the expression of complement factors is increased in conditions of elevated IOP [241-243]. The complement proteins C1q and C3 are crucial during retinal development by allowing the targeting of dysfunctional or unnecessary synapses to prune by microglial cells [244,245]. However, in glaucoma the inadequate targeting of synapses by increased expression of complement factors by microglia leads to indiscriminate pruning of healthy neurons, which might contribute to disease progression [246]. In addition, in glaucoma, microglia were found to actively phagocyte functional RGCs increasing the loss of visual capacity [246]. Furthermore, if neuron-microglia communication is impaired by interfering with the fractalkine receptor (CX3C chemokine receptor 1, Cx3cr1) in microglia, this would aggravate RGC loss in disease models such the ischemia-reperfusion [247] and glaucoma DBA/2J mouse [248], with no alterations in uninjured retinas [247]. These findings suggest that in the context of disease although the control of microglia response might be beneficial, it is important to preserve cell communication to restrain microglial cell response. Therefore, a strategy to confer protection to retinal cells might be to block the over targeting of retinal neurons by microglia through the complement system [241].

In the model of ischemia-reperfusion, treatment with minocycline, which decreases microglia reactivity, was able to protect RGCs [247]. Moreover, in the DBA/2J mouse model of glaucoma, minocycline decreases the number of ameboid microglia increasing their ramification and reducing the neuroinflammatory milieu [249]. Moreover, minocycline also improved axonal transport in RGCs and overall retinal integrity in the glaucoma model [249], providing evidence that the control of microglia-mediated neuroinflammation can have potential in RGC neuroprotection.

Müller cells are the main glial cells in the retina. In addition to structural support, among other functions, Müller cells are involved in metabolism, phagocytosis of neuronal debris and in the release of trophic factors. These cells can enhance the survival of RGCs [89,250-252].

Müller cells are crucial to protect neurons against toxic molecules (Figure 5). They can uptake excessive glutamate from the synapses, preventing glutamate-induced RGC death [253,254]. Some studies have demonstrated this function of Müller cells in vivo as well as in vitro [255-258]. The glutamate transporter GLAST contributes to the uptake of excess of glutamate from the medium protecting against the excitotoxic effect of glutamate [254,256]. Moreover, it has been shown that in some ocular diseases, the expression of GLAST is altered, including in an animal model of glaucoma [259]. Moreover, Müller cells are implicated in maintaining the retinal extracellular levels of other neurotransmitters, such as gamma-aminobutyric acid (GABA), contributing to neuronal protection [260].

Müller cells are also involved in the regulation of glycogen and glucose metabolism and during metabolic stress can provide lactate to retinal neurons [261]. For instance, in early phases of diabetic retinopathy, Müller glia may afford neuroprotection against high glucose [262]. In addition, due to their energy metabolism, Müller cells may protect neurons towards toxic stress by increasing ATP turnover [263]. Furthermore, they play a role in water and ion regulation, buffering the retina and inducing neuroprotection [250,264]. It is worth highlighting the important antioxidant role of Müller cells. One crucial molecule that protects the retina against reactive oxygen species is GSH, which can be synthesized by Müller cells [254,265]. In addition, GSH can prevent RGC degeneration in an experimental model of glaucoma [266]. 


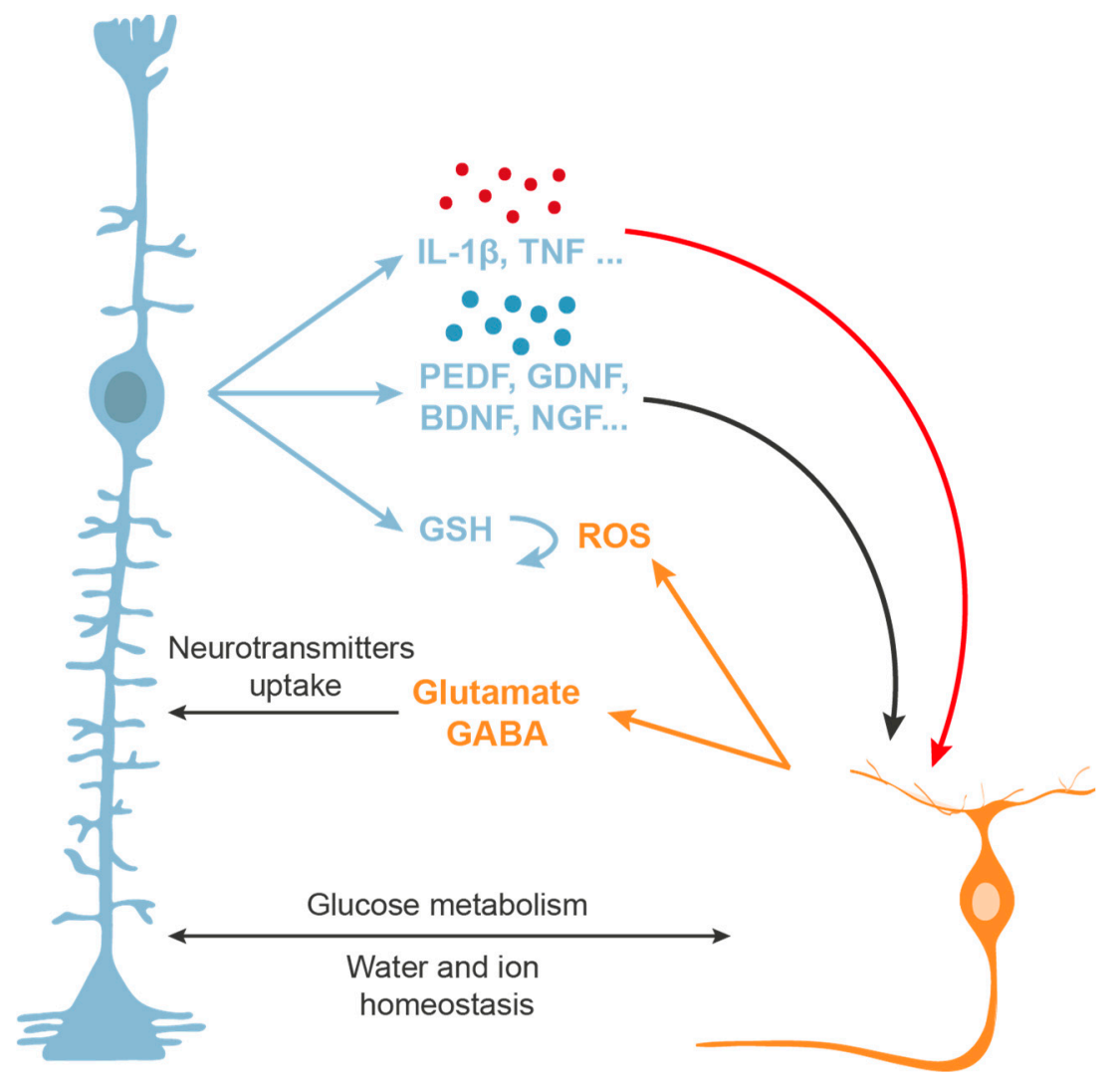

Figure 5. Diagram summarizing the main interactions of Müller cells (blue) with RGCs (orange). Scheme showing the roles of Müller cells in RGC neuroprotection, such as glucose metabolism regulation, water and ion homeostasis, neurotransmitters uptake, antioxidant defense systems (GSH) against ROS, secretion of trophic factors. The role of Müller cells in inflammation by secretion of cytokines that may be detrimental for RGCs is also depicted (red arrow).

Müller cells secrete a great number of factors in response to injury that can protect retinal neurons. Müller cells are known to synthesize neurotrophins and growth factors that can increase RGC survival [53,86,252,254], such as PEDF [267] or GDNF [105] among others. Moreover, Müller cells produce selective neurotrophins under different conditions, for instance, in response to glutamate, these cells upregulate the secretion of BDNF, NGF, NT-3, NT-4, and GDNF [268]. Müller cells are not only a source of neurotrophins, they also respond to neurotrophins as they express neurotrophin receptors [53,269] (see the neurotrophic factors functions protecting RGCs above).

Furthermore, Müller glial cells can release several inflammatory factors and cytokines [270], and some cytokines are even known to stimulate the production of other cytokines by Müller glia [271] in response to different stressors. Müller cells are a major source of retinal IL-1 $\beta$ [272,273] and they also secrete TNF, facilitating the apoptotic death of RGCs in response to damage $[274,275]$. In addition, Müller cells express toll-like receptors (TLRs) [276] and receptors for advanced glycation end-products (RAGE) [277] that induce the production of pro-inflammatory cytokines, chemokines and neuroprotective growth factors by these cells. In the beginning, this process acts as a protective mechanism to prevent further damage to the retina and to promote tissue repair. However, in the adult mammalian retina it does not appear to be beneficial since the release of pro-inflammatory cytokines and growth factors from Müller cells can lead to further degeneration [278]. For these reasons, understanding the processes in which Müller cells are involved and how these processes differ between pathological conditions and finding strategies to circumvent these barriers represent major challenges to the advancement of many ocular therapies. 


\section{Clinical Trials Targeting RGCs Neuroprotection}

A therapeutic strategy to optic neuropathies should protect RGCs from death but should also manipulate axonal regeneration in order to repair the visual function that was lost due to the disease. However, there is still no effective therapy for optic neuropathies. Innovative study designs and integrating therapeutic testing with biomarkers have advanced several neuroprotective and neuroenhancement compounds to clinical trials. Numerous neuroprotection strategies have been investigated for optic neuropathies, including peripheral nerve grafting, electrical stimulation, and in agreement with their well-known role in maintaining neuronal homeostasis, neurotrophic factors have been proposed as a novel therapy. However, the outcomes of the completed clinical trials were not completely satisfactory, presenting only partial or no expected effects [198,279-281].

There are several drugs in clinical trials that are currently being developed focused on RGC neuroprotection (Table 1). In the context of neurotrophic factors some clinical trials are available. NT-501 encapsulated cell therapy (NT-501 ECT) is a device produced by Neurotech that consists of an intravitreal implant with a capsule filled with human cells genetically modified to secrete CNTF. NT-501 ECT is in phase 2 for glaucoma (ClinicalTrials.gov Identifier: NCT02862938) and in phase 1 for ischemic optic neuropathy (ClinicalTrials.gov Identifier: NCT01411657). For glaucoma, other therapies have been proposed such as the use of recombinant human NGF (rhNGF) (ClinicalTrials.gov Identifier: NCT02855450). In this phase 1 clinical trial the safety and tolerability of an 8-week treatment with $180 \mu \mathrm{g} / \mathrm{mL}$ of rhNGF eye drop solution will be determined. Additionally, the study wants to assess the changes in best corrected distance visual acuity (BCDVA), visual field, electroretinography (ERG) and structural changes in GCL and NFL thickness measured by optical coherence tomography (OCT) at 1, 4 and 8 weeks of therapy, and at 4 and 24 weeks after therapy cessation. In another clinical trial the safety of treatment with single and multiple ascending doses of rhNGF $(0.5-180 \mu \mathrm{g} / \mathrm{mL})$ was tested in healthy patients (ClinicalTrials.gov Identifier: NCT01744704), and the results demonstrated that rhNGF eye drops were well tolerated by the patients [282].

The only modifiable risk factor for glaucoma development is elevated IOP. Brimonidine is a non-selective $\alpha 2$-adrenergic receptor agonist and is currently used as a treatment option in glaucoma to lower IOP [283]. Preclinical studies demonstrated the neuroprotective properties of brimonidine $[143,284]$, leading to the hypothesis that an implant with brimonidine can have beneficial properties for glaucoma patients. Indeed, this device is being evaluated in patients with glaucomatous optic neuropathy (ClinicalTrials.gov Identifier: NCT00693485). Moreover, cytidine-5'-diphosphocholine (citicoline) is also in a phase 4 clinical trial for glaucoma (ClinicalTrials.gov Identifier: NCT00404729). Citicoline is an endogenous molecule that has a role in the biosynthesis of phospholipids of cell membranes and increases the levels of neurotransmitters, like acetylcholine, in the CNS [285]. The neuroprotective properties of citicoline in glaucoma have been tested [286,287]. Intramuscular treatment of citicoline improves glaucomatous visual defects [286], RGC function (assessed by pattern ERG) and neural conduction along postretinal visual pathways (assessed by visual-evoked potential) [288]. That way, the phase 4 clinical trial aims to assess the effects of oral citicoline treatment in visual function outcomes in glaucoma patients. Memantine, a NMDA subtype of glutamate receptor antagonist, is already being used for Alzheimer's disease, and has undergone phase 3 clinical trials for glaucoma (ClinicalTrials.gov Identifier: NCT00141882 and NCT00168350). However, the drug did not show significant efficacy in preserving visual function in glaucoma patients [289]. 
Table 1. Drug-based therapies in clinical trials for optic neuropathies.

\begin{tabular}{|c|c|c|c|c|}
\hline Condition or Disease & Intervention & ClinicalTrials.gov Identifier & Phase & Starting Date \\
\hline Glaucoma & NT-501 ECT implant & NCT02862938 & 2 & 2016 \\
\hline Glaucoma & rhNGF & NCT02855450 & 1 & 2016 \\
\hline Glaucoma, Primary Open Angle & NT-501 CNTF Implant & NCT01408472 & 1 & 2011 \\
\hline Glaucoma, Open-Angle & Brimonidine Implant & NCT00693485 & 2 & 2008 \\
\hline Glaucoma and Ischemic optic neuropathy & Citicoline & NCT00404729 & 4 & 2006 \\
\hline Open-Angle Glaucoma & Memantine & NCT00141882 & 3 & 2005 \\
\hline Open-Angle Glaucoma & Memantine & NCT00168350 & 3 & 2005 \\
\hline Ischemic Optic Neuropathy & Alprostadil (prostaglandin E1) & NCT03851562 & 2 & 2019 \\
\hline Ischemic Optic Neuropathy & Bosentan & NCT02377271 & 3 & 2015 \\
\hline Ischemic Optic Neuropathy & Triamcinolone Acetonide & NCT02329288 & 3 & 2014 \\
\hline Ischemic Optic Neuropathy & NT-501 CNTF Implant & NCT01411657 & 1 & 2011 \\
\hline Non-arteritic Anterior Ischemic Optic Neuropathy & Prednisolone and Erythropoietin & NCT03715881 & 2 & 2018 \\
\hline Non-arteritic Ischemic Optic Neuropathy & RPh201 & NCT03547206 & 3 & 2018 \\
\hline Non-arteritic Anterior Ischemic Optic Neuropathy & Citicoline & NCT03046693 & 4 & 2017 \\
\hline Non-arteritic Anterior Ischemic Optic Neuropathy & Methylprednisolone & NCT02439866 & 3 & 2015 \\
\hline Non-arteritic Ischemic Optic Neuropathy & RPh201 & NCT02045212 & 2 & 2014 \\
\hline Non-arteritic Ischemic Optic Neuropathy & Dalfampridine & NCT01975324 & 4 & 2013 \\
\hline Non-arteritic Anterior Ischemic Optic Neuropathy & Avastin and Triamcinolone & NCT01330524 & 1 and 2 & 2011 \\
\hline Non-arteritic Anterior Ischemic Optic Neuropathy & Bevacizumab & NCT00813059 & 2 & 2008 \\
\hline Non-arteritic Anterior Ischemic Optic Neuropathy & Ranibizumab & NCT00561834 & 1 & 2007 \\
\hline Non-arteritic Anterior Ischemic Optic Neuropathy & Levodopa-carbidopa & NCT00432393 & 4 & 2007 \\
\hline
\end{tabular}


Table 1. Cont

\begin{tabular}{|c|c|c|c|c|}
\hline Condition or Disease & Intervention & ClinicalTrials.gov Identifier & Phase & Starting Date \\
\hline Traumatic Optic Neuropathy & Recombinant human erythropoietin & NCT03308448 & 3 & 2017 \\
\hline Traumatic Optic Neuropathy & Recombinant human erythropoietin & NCT01783847 & 1 and 2 & 2013 \\
\hline Optic Nerve Diseases (methanol associated optic neuropathy) & Erythropoietin & NCT02376881 & 3 & 2015 \\
\hline Leber's Hereditary Optic Neuropathy & Idebenone & NCT02774005 & 4 & 2016 \\
\hline Leber's Hereditary Optic Neuropathy & Cyclosporine & NCT02176733 & 2 & 2014 \\
\hline Leber's Hereditary Optic Neuropathy & Idebenone & NCT00747487 & 2 & 2008 \\
\hline
\end{tabular}


Moreover, prostaglandin E1 (alprostadil) administered by intravenous infusion, is very recently in phase 2 clinical trial (ClinicalTrials.gov Identifier: NCT03851562). Prostaglandin E1 is a potent vasodilator of the microcirculation [290], and may correct the deficits in the perfusion pressure of the microcirculation that supplies the optic nerve in patients with ischemic optic neuropathy, improving visual function. In fact, intravenous prostaglandin E1 is an effective treatment for ocular and optic nerve ischemia leading to immediate visual improvement [290]. On the other hand, due to the role of endothelin in glaucoma as a potent vasoconstrictor [291], the antagonism of its signaling seems to be a good therapeutic strategy for optic neuropathies. Bosentan, an endothelin receptor antagonist, is in phase 3 clinical trial for ischemic optic neuropathy in order to assess if the treatment could recover anatomical (NFL in OCT, optic atrophy) and functional (visual acuity, visual field) criteria (ClinicalTrials.gov Identifier: NCT02377271). The last drug-based therapy for ischemic optic neuropathy, the retrobulbar injection of triamcinolone acetonide to halt the progression of the visual acuity and visual field loss in patients improving their chances of avoiding blindness, is in phase 3 clinical trial (ClinicalTrials.gov Identifier: NCT02329288). In preclinical studies, besides the neuroprotective effects to RGCs conferred by triamcinolone acetonide, it was demonstrated that this drug also decreases the activation of retinal microglia [292]. For non-arteritic ischemic optic neuropathy there are several clinical trials targeting neuroprotection. EPO administered by intravenous injection started recently in phase 2 clinical trial, in order to assess visual field and thickness of the retinal NFL by OCT in glaucoma patients (ClinicalTrials.gov Identifier: NCT03715881). In the same clinical trial, another aim is to assess the potential retinal neuroprotective effect of prednisolone. Moreover, methylprednisolone is also in phase 3 clinical trial (ClinicalTrials.gov Identifier: NCT02439866). Preclinical studies demonstrated that methylprednisolone inhibits the apoptosis of RGCs after ONC, probably through an up-regulation of Bcl-2 expression and a down-regulation of Bax expression [293], two of the intrinsic factors that limit the axon regeneration described previously. Moreover, citicoline is in clinical trials for non-arteritic ischemic optic neuropathy (ClinicalTrials.gov Identifier: NCT03046693) in order to assess the function of RGCs by pattern ERG, thickness of GCL and visual field test.

$\mathrm{RPh} 201$ is a drug extracted from a botanical source and it has been produced by Regenera Pharma. RPh201 started recently the phase 3 clinical trial for non-arteritic ischemic optic neuropathy (ClinicalTrials.gov Identifier: NCT03547206). The results of the phase 2 clinical trial (ClinicalTrials.gov Identifier: NCT02045212) are already available. Patients showed an improvement in visual function after the treatment [294]. Dalfampridine is used to improve the walking ability in multiple sclerosis patients and is in a phase 4 clinical trial for non-arteritic ischemic optic neuropathy (ClinicalTrials.gov Identifier: NCT01975324).

Anti-VEGF antibodies (bevacizumab, avastin or ranibizumab) are used for the treatment of macular edema and neovascular age-related macular degeneration. However, they have also been tested for neuroprotection in optic neuropathies, and they are in three different clinical trials for non-arteritic anterior ischemic optic neuropathy (ClinicalTrials.gov Identifier: NCT01330524, NCT00813059 and NCT00561834) in order to halt the progression of visual acuity and visual field loss due to the disease. The thickness of GCL increased after the treatment with bevacizumab in diabetic macular edema [295]. Moreover, levodopa-carbidopa is used to treat the symptoms of Parkinson's disease and it is in a phase 4 clinical trial for non-arteritic anterior ischemic optic neuropathy (ClinicalTrials.gov Identifier: NCT00432393).

A phase 1 and 2 clinical trial (ClinicalTrials.gov Identifier: NCT01783847) assessing the effect of erythropoietin (EPO) demonstrated an improvement in visual function $[296,297]$. These beneficial effects can be due to the protection conferred to RGCs by EPO previously demonstrated in animal models of retinal degeneration [298]. Moreover, it has been tested whether EPO could improve optic nerve function and help patients to recover visual function after methanol associated optic neuropathy (ClinicalTrials.gov Identifier: NCT02376881). EPO is currently in phase 3 clinical trial for traumatic optic neuropathy (ClinicalTrials.gov Identifier: NCT03308448). 
Leber's hereditary optic neuropathy is an inherited optic neuropathy characterized by mitochondrial dysfunction that leads to vision loss due to RGCs loss [299]. Idebenone was in clinical trials for the treatment of vision loss due to Leber's hereditary optic neuropathy (ClinicalTrials.gov Identifier: NCT02774005 and NCT00747487). The beneficial effects of idebenone are due to its antioxidant properties and its ability to act as an electron carrier in the mitochondrial respiratory chain, thus resulting in the restoration of cellular energy (ATP) generation and contributing to the recovery of visual function in patients (reviewed in [300]). That way, idebenone (Raxone ${ }^{\circledR}$ ) is the first, and currently the only disease-specific treatment for Leber's hereditary optic neuropathy and the only approved for optic neuropathies aiming RGCs neuroprotection. Moreover, cyclosporine is also in a phase 2 clinical trial for Leber's hereditary optic neuropathy (ClinicalTrials.gov Identifier: NCT02176733), due to protective properties against ischemic injury-mediated mitochondrial dysfunction in RGCs [301].

Currently, there are two clinical trials involving stem-cell based therapies targeting RGCs (Table 2). One trial aims to assess the safety and efficacy of the transplantation of autologous purified stem cells (ClinicalTrials.gov Identifier: NCT02638714) on restoring function in damaged optic nerves using autologous purified populations of bone-marrow derived stem cells in optic neuropathy. The intravitreal injection of MSCs (ClinicalTrials.gov Identifier: NCT03173638) aims to evaluate if the treatment may reduce the progression of axonal degeneration caused by non-arteritic ischemic optic neuropathy, but this clinical trial is focused in the evaluation of the safety of cell therapy as a new treatment for these patients.

Table 2. Stem cell-based therapies in clinical trials for optic neuropathies.

\begin{tabular}{ccccc}
\hline Condition or Disease & Intervention & $\begin{array}{c}\text { ClinicalTrials.gov } \\
\text { Identifier }\end{array}$ & Phase & Starting Date \\
\hline Optic Neuropathy & $\begin{array}{c}\text { Transplantation of autologous } \\
\text { purified stem cells }\end{array}$ & NCT02638714 & 1 and 2 & 2015 \\
\hline $\begin{array}{c}\text { Non-arteritic Ischemic } \\
\text { Optic Neuropathy }\end{array}$ & $\begin{array}{c}\text { Intravitreal injection of } \\
\text { mesenchymal stem cells }\end{array}$ & NCT03173638 & 2 & 2017 \\
\hline
\end{tabular}

\section{Different Types of RGCs and their Susceptibility after Retinal Damage}

The complexity of the CNS is due to the great number of specialized neuronal types and subtypes that give rise to a complex connectome [302]. However, due to the heterogeneity and complexity of the mammalian neuronal types, neuronal classification has been challenging and many cell subtypes have not yet been characterized [303]. Just like neurons in the brain, in the retina, although most RGCs serve a similar function, it was proven that these RGCs are highly diverse. The total RGC population develops from a common precursor into different subtypes of RGCs, with that they may differ in their physiological roles generating varied responses to visual stimuli [304]. RGCs have been classified based on differences in size, morphology, dendritic arborization, electrophysiological functions, susceptibility to degeneration, regenerative capacity and expression of specific molecular signatures, and more than thirty different subtypes of RGCs subtypes have been identified to date in the mammalian retina [305]. In 1953, the first classifications were made and the ON- and OFFcenter RGCs were distinguished [305]. In recent works, combining different criteria, RGCs were classified into four types of ON-OFF directionally selective ganglion cells (DS-RGCs), three types of ON DS-RGCs, three types of alpha RGCs (sustained ON, sustained OFF, and transient OFF $\alpha$ RGCs), five types of intrinsically photosensitive melanopsin-containing RGCs (ipRGCs), three types of JamB expressing RGCs (J-RGCs), two types of beta cells ( $\beta$ RGCs), chromatically sensitive ganglion cells, orientation-sensitive cells, and suppressed-by-contrast cells, among others [306].

The major requirement to properly characterize and classify RGCs is to distinguish selectively each specific subtype. Thus, recently, a number of molecular subtype-specific markers have been described to further classify different subtypes of RGCs [307]. Several markers are being proposed, but most of them sign more than a single RGC subtype. Four types of ON-OFF DS-RGCs have been 
described, depending on the direction of the moving object to which they respond. They all have similar dendritic stratification and express CART (cocaine and amphetamine-regulated transcript) [308]. DS-RGCs have been also identified by the expression of specific molecular markers, such as CDH6 and FSTL4 [307]. Moreover, the ON DS-RGCs can be identified by the expression of the secretory protein SPIG1 [309]. In addition, three types of $\alpha$-RGCs express similar markers, including neurofilaments, spp1 and kcng4, among others [310], although they differ in their physiological properties, dendritic arborization and stratification in the IPL [306]. On the other hand, the ipRGCs mediate many relevant non-image forming functions of the eye and they are identified by the expression of the photopigment melanopsin [311].

Another molecular marker, Tbr2, identifies RGCs that are hardwired during developmental stages and they could be precursors of ipRGCs [312]. Other single subtype of RGCs appears to be uniquely marked by the transcription factor Prdm16. However, the precise identity of these RGCs is unclear, but they most resemble the G9 subtype described by Völgyi and colleagues in 2009 [313].

Moreover, mouse transgenic lines have been also used to label and identify specific subsets of RGCs [314]. For instance, the line CB2-GFP labels transient OFF $\alpha$ RGCs [315] and the line Isl2-GFP labels $\alpha$ RGCs but not ON-OFF DS-RGCs [316]. In addition, using single cell transcriptome profiling of RGCs, specific markers for cellular subtypes have been identified, such as Zic1, Runx1 and Fst [317]. This capacity to successfully identify RGCs subtypes hopefully will help to understand the different susceptibility of certain RGCs to progression of pathologies like glaucoma.

In order to understand the pathophysiology of neurodegenerative diseases in which the RGCs death is implicated, it is important to analyze the response of these RGCs subtypes individually rather than studying them as a single entity. RGCs are susceptible to various injuries in a type-specific manner. Thereby, their type-specific vulnerability has been extensively studied [318]. The identification and characterization of the loss of specific RGCs subtypes in axotomy [310], ONC [319] and glaucoma [320] models has been analyzed, suggesting subtype specific responses to injury. The importance of studying the response of these subtypes individually rather than studying them as a single entity could help us understand the pathophysiology of diseases in which RGCs are affected. For instance, it was found that a greater loss of large RGCs in the peripheral retina occur in a pig glaucoma model resembling what was described in glaucoma patients [321]. However, in the periphery of the retina, some cells are resistant to damage, and it will be very important to know the nature of the cells that possess the capacity to recover after an insult. The $\alpha$ RGCs seem to be the least susceptible RGCs subtype to optic nerve injury [310]. The $\alpha$ RGCs are also the most resistant RGCs to NMDA excitotoxicity, while the J-RGCs are the most sensitive to the same damage [322]. Nevertheless, $\alpha$ RGCs seem to be the more susceptible RGCs subtype in other studies, such as in autoimmune optic neuritis, where $\alpha$ RGCs are more vulnerable to degeneration than ON $\alpha$ RGCs [323], and after ONC injury, where OFF-transient $\alpha$ RGCs are the most susceptible to injury followed by ON-OFF DS-RGCs [319]. In experimental models of OHT, OFF-transient RGCs exhibited a faster decline on survival when compared to ON RGCs, and they were also the first to undergo structural alterations [318]. Similarly, after ONC injury, functional responses and receptive fields of OFF cells were also impaired earlier than ON cells, and ON sustained RGCs seem to be more susceptible than ON transient RGCs [324]. In another model of OHT, the mono-laminated ON RGCs were more susceptible to chronic OHT than bi-laminated ON-OFF cells [325].

It has been shown that non-image forming ipRGCs exhibited a preferential survival following injury compared to image forming RGCs. This fact was observed in different injury and disease models, demonstrating the resilience to damage of this subtype of RGCs [326]. ipRGCs have the ability to respond to light using the photopigment melanopsin, and they play a role in circadian rhythms and pupillary reflexes through their projections to the suprachiasmatic nucleus and the olivary pretectal nucleus [327]. This unique feature may be the basis of their resistance to insult, as these cells are not necessary for the formation of images in the visual transduction pathway [328]. 
All these studies clearly imply that RGCs respond in a subtype specific manner to injury. Moreover, each subtype of RGCs can have a unique gene expression pattern [306,329], this differential gene expression may protect some types of RGCs and facilitate the death of others [330]. Therefore, the analysis of the type-specific vulnerability of RGCs based on their gene expression may provide insights of the selective vulnerability of RGCs to pathological insults and to better understand disease mechanisms [322]. Moreover, further studies are needed to determine how the molecular differences between RGCs subtypes underlie their electrophysiological functions, and it is necessary to investigate whether they differ in morphology, retinal spatial distribution, target cell connectivity, and associated visual parameters. These studies could provide a new opportunity to the development of strategies to target specific subtypes of RGCs for diagnostic and therapeutic approaches to treat optic neuropathies, such as glaucoma.

\section{Potential Pitfalls in Translating Preclinical Studies into the Clinics}

The main goal in finding new therapeutic strategies for optic neuropathies is to preserve the function of RGCs in order to maintain visual pathways. Therefore, besides the neuroprotection of RGCs and axon regeneration, the re-integration of RGC axons into the appropriate visual circuity is also important. Despite that several therapeutic strategies have demonstrated promising results in this field, there are significant issues affecting their translation to clinical practice.

Much work has been done in order to identify the inhibitors of axonal growth in the CNS as well as to isolate neurotrophic factors, with the hope that one day these factors could be applied to protect and regenerate the optic nerve. From what was described above, it seems that we are getting closer to a therapeutic strategy focused on RGC neuroprotection for optic neuropathies. However, we can discuss the example of memantine that, despite the convincing neuroprotective effects in animal models of glaucoma, in clinical trials the drug did not reveal significant effects in preventing the progression of visual field loss in patients with glaucoma [289].

Several issues contributing to the lack of success of drugs in clinical trials could be suggested, but in the case of glaucoma, the lack of an animal model that fully mimics the human disease is an important factor that adds to this failure [331]. Another issue is that, in preclinical trials, several studies use a preventive strategy to assess the effect of a specific drug, as opposed to the human condition in which the treatment starts after diagnosis. Moreover, in most of the animal studies the evaluation of the drug beneficial effects occurs by histopathological methodologies, and this is not possible in human studies. The increasingly use of OCT and ERG in preclinical studies will benefit the translation of what is observed in an animal models of disease into human.

Besides the protection of RGCs from death and degeneration, one of the goals in RGCs regeneration therapies should be to allow the reintegration of the regenerating axons into visual circuity reaching the appropriate brain targets. However, there are few studies that focus on this issue [26]. Moreover, the identification of different types of RGCs and the characterization of their different susceptibility to disease $[306,324]$ may also contribute to the failure of the therapeutic strategies with high potential of success in the clinical trials phase.

It is fundamental a better characterization of the beneficial effects of drugs in the preclinical phase, meaning that the observation of the loss of RGCs is not enough as it is not enough to observe potential regenerative events of the axons of RGCs. It is essential to clearly and more deeply evaluate the beneficial effects of a specific new drug also in visual function.

The research in the field of neuroprotection in glaucoma has been difficult, but new animal models of disease and techniques will help to bridge the gap between preclinical and clinical studies, with clear beneficial outcomes in the forthcoming years. Many of the approaches outlined in this review are applicable not only to RGC neuroprotection in glaucoma but also to other pathologies of the optic nerve and retina. Gene therapy may have also a therapeutic potential especially for Leber's hereditary optic neuropathy, an optic neuropathy caused by mitochondrial mutation G11778A in NADH dehydrogenase subunit 4 (ND4) gene [332]. It was conducted in patients and the recombinant adeno-associated 
virus 2 (AAV2) carrying ND4 (rAAV2-ND4) demonstrated to improve patients visual acuity [333-335]. In addition, CRISPR/Cas9-based therapies are starting to be applied making significant progress in mammalian preclinical models of eye disease such as blind rodents [336] or in the disruption of mutant genes that cause certain forms of glaucoma [337]. Applications of CRISPR/Cas9 technology and other gene therapies may soon be available, not only as research tools but also as therapies to treat retinal diseases.

Author Contributions: Conceptualization, R.B. and A.R.S.; writing-original draft, R.B., N.R., I.D.A. and X.P.; writing-review and editing, R.B., N.R., I.D.A., X.P., A.F.A., E.V. and A.R.S. All authors have read and agreed to the published version of the manuscript.

Funding: This work was supported by Foundation for Science and Technology (FCT), Portugal (Fellowships PD/BD/114115/2015 and PD/BD/127821/2016, Grant PTDC/NEU-OSD/3123/2014 and Strategic Projects UID/NEU/04539/2013, UID/NEU/04539/2019, UIDP/04539/2020 and UIDB/04539/2020), FEDER-COMPETE POCI-01-0145-FEDER-016849, FCOMP-01-0124-FEDER-028417, POCI-01-0145-FEDER-007440) and Centro 2020 Regional Operational Programme (CENTRO-01-0145-FEDER-000008: BrainHealth 2020). Grupos UPV/EHU GIU18/50, PUE 2018-04 and ELKARTEK KK-2019/00086 to E.V.

Acknowledgments: We thank Sara Boia for providing the illustration in Figure 1.

Conflicts of Interest: The authors declare no conflict of interest.

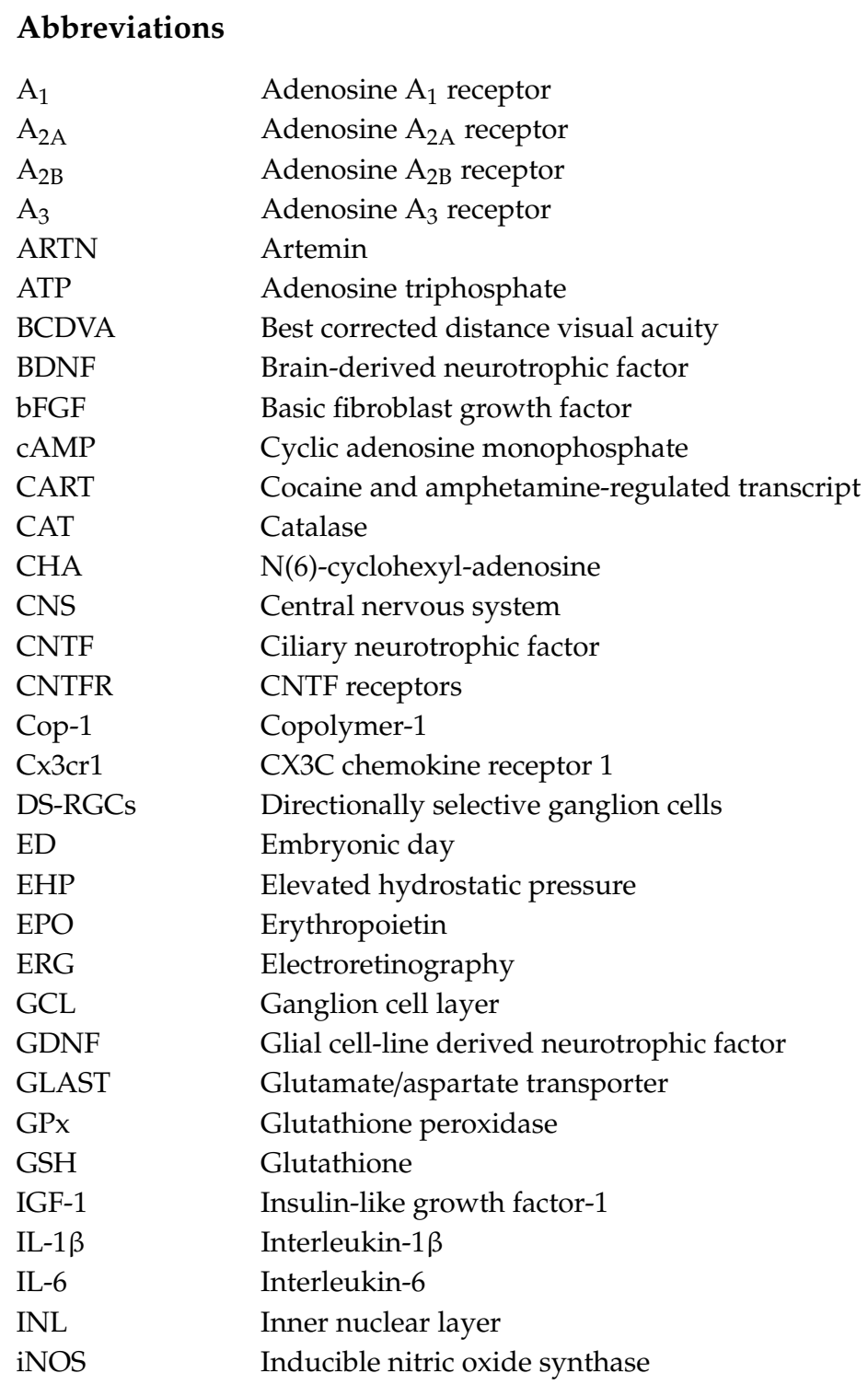




\begin{tabular}{|c|c|}
\hline IOP & Intraocular pressure \\
\hline ipRGCs & Intrinsically photosensitive melanopsin-containing RGCs \\
\hline J-RGCs & JamB expressing RGCs \\
\hline KLF & Krüppel-like family \\
\hline MAG & Myelin-associated glycoprotein \\
\hline MHC-II & Major histocompatibility complex class II \\
\hline mTOR & Mammalian target of rapamycin \\
\hline ND4 & NADH dehydrogenase subunit 4 \\
\hline NFL & Nerve fiber layer \\
\hline NGF & Nerve growth factor \\
\hline $\mathrm{NgR}$ & Nogo receptor \\
\hline NLRP3 & NOD-, LRR- and pyrin domain-containing protein 3 \\
\hline NMDA & N-methyl-D-aspartate \\
\hline NO & Nitric oxide \\
\hline NOS & Nitric oxide synthase \\
\hline NRTN & Neurturin \\
\hline NT-3 & Neurotrophin-3 \\
\hline NT-4/5 & Neurotrophin- $4 / 5$ \\
\hline OCT & Optical coherence tomography \\
\hline OHT & Ocular hypertension \\
\hline ONC & Optic nerve crush \\
\hline $\mathrm{ONH}$ & Optic nerve head \\
\hline ONL & Outer nuclear layer \\
\hline PEDF & Pigment epithelium derived factor \\
\hline PI3K & Phosphoinositide 3-kinases \\
\hline PND & Postnatal day \\
\hline PNS & Peripheral nervous system \\
\hline PSPN & Persephin \\
\hline PTEN & Phosphatase and tensin homologue \\
\hline RAGE & Receptors for advanced glycation end-products \\
\hline RGCs & Retinal ganglion cells \\
\hline rhNGF & Recombinant human nerve growth factor \\
\hline ROS & Reactive oxygen species \\
\hline Sema3A & Semaphorin-3A \\
\hline Sema5A & Semaphorin-5A \\
\hline SOD & Superoxide dismutase \\
\hline TLRs & Toll-like receptors \\
\hline TNF & Tumour necrosis factor \\
\hline TrK & Tyrosine kinase \\
\hline TSPO & Translocator protein \\
\hline VEGF-A & Vascular endothelial growth factor A \\
\hline $\mathrm{Zn}^{2+}$ & Zinc \\
\hline$\alpha$ RGCs & alpha retinal ganglion cells \\
\hline$\beta$ RGCs & beta retinal ganglion cells \\
\hline
\end{tabular}

\section{References}

1. Kolb, H.; Fernandez, E.; Nelson, R. Webvision: The Organization of the Retina and Visual System. In Webvision: The Organization of the Retina and Visual System; Kolb, H., Fernandez, E., Nelson, R., Eds.; University of Utah Health Sciences Center: Salt Lake City, UT, USA, 1995.

2. Carelli, V.; La Morgia, C.; Ross-Cisneros, F.N.; Sadun, A.A. Optic neuropathies: The tip of the neurodegeneration iceberg. Hum. Mol. Genet. 2017, 26, R139-R150. [CrossRef] [PubMed]

3. Goldberg, J.L.; Espinosa, J.S.; Xu, Y.; Davidson, N.; Kovacs, G.T.; Barres, B.A. Retinal ganglion cells do not extend axons by default: Promotion by neurotrophic signaling and electrical activity. Neuron 2002, 33, 689-702. [CrossRef] 
4. Dratviman-Storobinsky, O.; Hasanreisoglu, M.; Offen, D.; Barhum, Y.; Weinberger, D.; Goldenberg-Cohen, N. Progressive damage along the optic nerve following induction of crush injury or rodent anterior ischemic optic neuropathy in transgenic mice. Mol. Vis. 2008, 14, 2171-2179. [PubMed]

5. Kutsarova, E.; Munz, M.; Ruthazer, E.S. Rules for shaping neural connections in the developing brain. Front. Neural Circuits 2016, 10, 111. [CrossRef]

6. Guerin, M.B.; McKernan, D.P.; O’Brien, C.J.; Cotter, T.G. Retinal ganglion cells: Dying to survive. Int. J. Dev. Biol. 2006, 50, 665-674. [CrossRef]

7. Goldberg, J.L.; Klassen, M.P.; Hua, Y.; Barres, B.A. Amacrine-signaled loss of intrinsic axon growth ability by retinal ganglion cells. Science 2002, 296, 1860-1864. [CrossRef]

8. Martins, J.; Elvas, F.; Brudzewsky, D.; Martins, T.; Kolomiets, B.; Tralhao, P.; Gotzsche, C.R.; Cavadas, C.; Castelo-Branco, M.; Woldbye, D.P.; et al. Activation of neuropeptide y receptors modulates retinal ganglion cell physiology and exerts neuroprotective actions in vitro. ASN Neuro 2015, 7. [CrossRef]

9. Barres, B.A.; Silverstein, B.E.; Corey, D.P.; Chun, L.L. Immunological, morphological, and electrophysiological variation among retinal ganglion cells purified by panning. Neuron 1988, 1, 791-803. [CrossRef]

10. Ming, G.L.; Song, H.J.; Berninger, B.; Holt, C.E.; Tessier-Lavigne, M.; Poo, M.M. cAMP-dependent growth cone guidance by netrin-1. Neuron 1997, 19, 1225-1235. [CrossRef]

11. Rodger, J.; Goto, H.; Cui, Q.; Chen, P.B.; Harvey, A.R. cAMP regulates axon outgrowth and guidance during optic nerve regeneration in goldfish. Mol. Cell. Neurosci. 2005, 30, 452-464. [CrossRef]

12. Park, K.K.; Liu, K.; Hu, Y.; Smith, P.D.; Wang, C.; Cai, B.; Xu, B.; Connolly, L.; Kramvis, I.; Sahin, M.; et al. Promoting axon regeneration in the adult CNS by modulation of the PTEN/mTOR pathway. Science 2008, 322, 963-966. [CrossRef] [PubMed]

13. Huang, Z.R.; Chen, H.Y.; Hu, Z.Z.; Xie, P.; Liu, Q.H. PTEN knockdown with the Y444F mutant AAV2 vector promotes axonal regeneration in the adult optic nerve. Neural Regen. Res. 2018, 13, 135-144. [CrossRef] [PubMed]

14. Moore, D.L.; Blackmore, M.G.; Hu, Y.; Kaestner, K.H.; Bixby, J.L.; Lemmon, V.P.; Goldberg, J.L. KLF family members regulate intrinsic axon regeneration ability. Science 2009, 326, 298-301. [CrossRef] [PubMed]

15. Steketee, M.B.; Oboudiyat, C.; Daneman, R.; Trakhtenberg, E.; Lamoureux, P.; Weinstein, J.E.; Heidemann, S.; Barres, B.A.; Goldberg, J.L. Regulation of intrinsic axon growth ability at retinal ganglion cell growth cones. Investig. Ophthalmol. Vis. Sci. 2014, 55, 4369-4377. [CrossRef] [PubMed]

16. Li, Y.; Andereggen, L.; Yuki, K.; Omura, K.; Yin, Y.; Gilbert, H.Y.; Erdogan, B.; Asdourian, M.S.; Shrock, C.; de Lima, S.; et al. Mobile zinc increases rapidly in the retina after optic nerve injury and regulates ganglion cell survival and optic nerve regeneration. Proc. Natl. Acad. Sci. USA 2017, 114, E209-E218. [CrossRef]

17. Moore, D.L.; Goldberg, J.L. Multiple transcription factor families regulate axon growth and regeneration. Dev. Neurobiol. 2011, 71, 1186-1211. [CrossRef]

18. Li, Y.; Schlamp, C.L.; Poulsen, G.L.; Jackson, M.W.; Griep, A.E.; Nickells, R.W. p53 regulates apoptotic retinal ganglion cell death induced by N-methyl-D-aspartate. Mol. Vis. 2002, 8, 341-350.

19. Di Giovanni, S.; Knights, C.D.; Rao, M.; Yakovlev, A.; Beers, J.; Catania, J.; Avantaggiati, M.L.; Faden, A.I. The tumor suppressor protein p53 is required for neurite outgrowth and axon regeneration. EMBO J. 2006, 25, 4084-4096. [CrossRef]

20. Maes, M.E.; Schlamp, C.L.; Nickells, R.W. BAX to basics: How the BCL2 gene family controls the death of retinal ganglion cells. Prog. Retin. Eye Res. 2017, 57, 1-25. [CrossRef]

21. Isenmann, S.; Wahl, C.; Krajewski, S.; Reed, J.C.; Bahr, M. Up-regulation of Bax protein in degenerating retinal ganglion cells precedes apoptotic cell death after optic nerve lesion in the rat. Eur. J. Neurosci. 1997, 9, 1763-1772. [CrossRef]

22. Kaneda, K.; Kashii, S.; Kurosawa, T.; Kaneko, S.; Akaike, A.; Honda, Y.; Minami, M.; Satoh, M. Apoptotic DNA fragmentation and upregulation of Bax induced by transient ischemia of the rat retina. Brain Res. 1999, 815, 11-20. [CrossRef]

23. Libby, R.T.; Li, Y.; Savinova, O.V.; Barter, J.; Smith, R.S.; Nickells, R.W.; John, S.W. Susceptibility to neurodegeneration in a glaucoma is modified by Bax gene dosage. PLoS Genet. 2005, 1, 17-26. [CrossRef] [PubMed]

24. Chen, D.F.; Schneider, G.E.; Martinou, J.C.; Tonegawa, S. Bcl-2 promotes regeneration of severed axons in mammalian CNS. Nature 1997, 385, 434-439. [CrossRef] [PubMed] 
25. Richardson, P.M.; McGuinness, U.M.; Aguayo, A.J. Axons from CNS neurones regenerate into PNS grafts. Nature 1980, 284, 264-265. [CrossRef]

26. Vidal-Sanz, M.; Bray, G.M.; Villegas-Perez, M.P.; Thanos, S.; Aguayo, A.J. Axonal regeneration and synapse formation in the superior colliculus by retinal ganglion cells in the adult rat. J. Neurosci. Off. J. Soc. Neurosci. 1987, 7, 2894-2909. [CrossRef]

27. Yiu, G.; He, Z. Glial inhibition of CNS axon regeneration. Nat. Rev. Neurosci. 2006, 7, 617-627. [CrossRef]

28. Pasterkamp, R.J.; Giger, R.J.; Ruitenberg, M.J.; Holtmaat, A.J.; De Wit, J.; De Winter, F.; Verhaagen, J. Expression of the gene encoding the chemorepellent semaphorin III is induced in the fibroblast component of neural scar tissue formed following injuries of adult but not neonatal CNS. Mol. Cell. Neurosci. 1999, 13, 143-166. [CrossRef]

29. Pasterkamp, R.J.; Anderson, P.N.; Verhaagen, J. Peripheral nerve injury fails to induce growth of lesioned ascending dorsal column axons into spinal cord scar tissue expressing the axon repellent Semaphorin3A. Eur. J. Neurosci. 2001, 13, 457-471. [CrossRef]

30. Van Horck, F.P.G.; Weinl, C.; Holt, C.E. Retinal axon guidance: Novel mechanisms for steering. Curr. Opin. Neurobiol. 2004, 14, 61-66. [CrossRef]

31. Tillo, M.; Ruhrberg, C.; Mackenzie, F. Emerging roles for semaphorins and VEGFs in synaptogenesis and synaptic plasticity. Cell Adhes. Migr. 2012, 6, 541-546. [CrossRef]

32. Chan-Juan, H.; Sen, L.; Li-Qianyu, A.; Jian, Y.; Rong-Di, Y. MicroRNA-30b regulates the polarity of retinal ganglion cells by inhibiting semaphorin-3A. Mol. Vis. 2019, 25, 722-730. [PubMed]

33. Dallimore, E.J.; Cui, Q.; Beazley, L.D.; Harvey, A.R. Postnatal innervation of the rat superior colliculus by axons of late-born retinal ganglion cells. Eur. J. Neurosci. 2002, 16, 1295-1304. [CrossRef] [PubMed]

34. De Winter, F.; Cui, Q.; Symons, N.; Verhaagen, J.; Harvey, A.R. Expression of class-3 semaphorins and their receptors in the neonatal and adult rat retina. Investig. Ophthalmol. Vis. Sci. 2004, 45, 4554-4562. [CrossRef]

35. Zylbersztejn, K.; Petkovic, M.; Burgo, A.; Deck, M.; Garel, S.; Marcos, S.; Bloch-Gallego, E.; Nothias, F.; Serini, G.; Bagnard, D.; et al. The vesicular SNARE Synaptobrevin is required for Semaphorin 3A axonal repulsion. J. Cell Biol. 2012, 196, 37-46. [CrossRef]

36. Shirvan, A.; Kimron, M.; Holdengreber, V.; Ziv, I.; Ben-Shaul, Y.; Melamed, S.; Melamed, E.; Barzilai, A.; Solomon, A.S. Anti-semaphorin 3A antibodies rescue retinal ganglion cells from cell death following optic nerve axotomy. J. Biol. Chem. 2002, 277, 49799-49807. [CrossRef]

37. Goldberg, J.L.; Vargas, M.E.; Wang, J.T.; Mandemakers, W.; Oster, S.F.; Sretavan, D.W.; Barres, B.A. An oligodendrocyte lineage-specific semaphorin, Sema5A, inhibits axon growth by retinal ganglion cells. J. Neurosci. Off. J. Soc. Neurosci. 2004, 24, 4989-4999. [CrossRef]

38. Fisher, J.; Levkovitch-Verbin, H.; Schori, H.; Yoles, E.; Butovsky, O.; Kaye, J.F.; Ben-Nun, A.; Schwartz, M. Vaccination for neuroprotection in the mouse optic nerve: Implications for optic neuropathies. J. Neurosci. 2001, 21, 136-142. [CrossRef]

39. Kipnis, J.; Yoles, E.; Porat, Z.; Cohen, A.; Mor, F.; Sela, M.; Cohen, I.R.; Schwartz, M. T cell immunity to copolymer 1 confers neuroprotection on the damaged optic nerve: Possible therapy for optic neuropathies. Proc. Natl. Acad. Sci. USA 2000, 97, 7446-7451. [CrossRef]

40. Schori, H.; Kipnis, J.; Yoles, E.; WoldeMussie, E.; Ruiz, G.; Wheeler, L.A.; Schwartz, M. Vaccination for protection of retinal ganglion cells against death from glutamate cytotoxicity and ocular hypertension: Implications for glaucoma. Proc. Natl. Acad. Sci. USA 2001, 98, 3398-3403. [CrossRef]

41. Bakalash, S.; Ben-Shlomo, G.; Aloni, E.; Shaked, I.; Wheeler, L.; Ofri, R.; Schwartz, M. T-cell-based vaccination for morphological and functional neuroprotection in a rat model of chronically elevated intraocular pressure. J. Mol. Med. 2005, 83, 904-916. [CrossRef]

42. Pernet, V.; Joly, S.; Christ, F.; Dimou, L.; Schwab, M.E. Nogo-A and myelin-associated glycoprotein differently regulate oligodendrocyte maturation and myelin formation. J. Neurosci. Off. J. Soc. Neurosci. 2008, 28, 7435-7444. [CrossRef] [PubMed]

43. Pernet, V. Nogo-A in the visual system development and in ocular diseases. Biochim. Biophys. Acta Mol. Basis Dis. 2017, 1863, 1300-1311. [CrossRef] [PubMed]

44. Solomon, A.M.; Westbrook, T.; Field, G.D.; McGee, A.W. Nogo receptor 1 is expressed by nearly all retinal ganglion cells. PLOS ONE 2018, 13, e0196565. [CrossRef] [PubMed] 
45. Pernet, V.; Joly, S.; Dalkara, D.; Schwarz, O.; Christ, F.; Schaffer, D.; Flannery, J.G.; Schwab, M.E. Neuronal Nogo-A upregulation does not contribute to ER stress-associated apoptosis but participates in the regenerative response in the axotomized adult retina. Cell Death Differ. 2012, 19, 1096-1108. [CrossRef] [PubMed]

46. Vajda, F.; Jordi, N.; Dalkara, D.; Joly, S.; Christ, F.; Tews, B.; Schwab, M.E.; Pernet, V. Cell type-specific Nogo-A gene ablation promotes axonal regeneration in the injured adult optic nerve. Cell Death Differ. 2015, 22, 323-335. [CrossRef] [PubMed]

47. Mdzomba, J.B.; Jordi, N.; Rodriguez, L.; Joly, S.; Bretzner, F.; Pernet, V. Nogo-A inactivation improves visual plasticity and recovery after retinal injury. Cell Death Dis. 2018, 9, 727. [CrossRef]

48. Wong, E.V.; David, S.; Jacob, M.H.; Jay, D.G. Inactivation of myelin-associated glycoprotein enhances optic nerve regeneration. J. Neurosci. Off. J. Soc. Neurosci. 2003, 23, 3112-3117. [CrossRef]

49. Liao, X.-X.; Chen, D.; Shi, J.; Sun, Y.-Q.; Sun, S.-J.; So, K.-F.; Fu, Q.-L. The expression patterns of Nogo-A, Myelin Associated Glycoprotein and Oligodendrocyte Myelin Glycoprotein in the Retina After Ocular hypertension. Neurochem. Res. 2011, 36, 1955-1961. [CrossRef]

50. Fu, Q.-L.; Liao, X.-X.; Li, X.; Chen, D.; Shi, J.; Wen, W.; Lee, D.H.S.; So, K.-F. Soluble Nogo-66 receptor prevents synaptic dysfunction and rescues retinal ganglion cell loss in chronic glaucoma. Investig. Opthalmol. Vis. Sci. 2011, 52, 8374. [CrossRef]

51. Su, Y.; Wang, F.; Teng, Y.; Zhao, S.G.; Cui, H.; Pan, S.H. Axonal regeneration of optic nerve after crush in Nogo66 receptor knockout mice. Neurosci. Lett. 2009, 460, 223-226. [CrossRef]

52. Vecino, E.; Ugarte, M.; Nash, M.S.; Osborne, N.N. NMDA induces BDNF expression in the albino rat retina in vivo. Neuroreport 1999, 10, 1103-1106. [CrossRef] [PubMed]

53. Vecino, E.; Caminos, E.; Ugarte, M.; Martin-Zanca, D.; Osborne, N.N. Immunohistochemical distribution of neurotrophins and their receptors in the rat retina and the effects of ischemia and reperfusion. Gen. Pharmacol. 1998, 30, 305-314. [CrossRef]

54. Hofer, M.; Pagliusi, S.R.; Hohn, A.; Leibrock, J.; Barde, Y.A. Regional distribution of brain-derived neurotrophic factor mRNA in the adult mouse brain. EMBO J. 1990, 9, 2459-2464. [CrossRef] [PubMed]

55. Wetmore, C.; Ernfors, P.; Persson, H.; Olson, L. Localization of brain-derived neurotrophic factor mRNA to neurons in the brain by in situ hybridization. Exp. Neurol. 1990, 109, 141-152. [CrossRef]

56. Herzog, K.H.; von Bartheld, C.S. Contributions of the optic tectum and the retina as sources of brain-derived neurotrophic factor for retinal ganglion cells in the chick embryo. J. Neurosci. Off. J. Soc. Neurosci. 1998, 18, 2891-2906. [CrossRef]

57. Ma, Y.T.; Hsieh, T.; Forbes, M.E.; Johnson, J.E.; Frost, D.O. BDNF injected into the superior colliculus reduces developmental retinal ganglion cell death. J. Neurosci. Off. J. Soc. Neurosci. 1998, 18, 2097-2107. [CrossRef]

58. Di Polo, A.; Aigner, L.J.; Dunn, R.J.; Bray, G.M.; Aguayo, A.J. Prolonged delivery of brain-derived neurotrophic factor by adenovirus-infected Muller cells temporarily rescues injured retinal ganglion cells. Proc. Natl. Acad. Sci. USA 1998, 95, 3978-3983. [CrossRef]

59. Chen, H.; Weber, A.J. BDNF enhances retinal ganglion cell survival in cats with optic nerve damage. Investig. Ophthalmol. Vis. Sci. 2001, 42, 966-974.

60. Mey, J.; Thanos, S. Intravitreal injections of neurotrophic factors support the survival of axotomized retinal ganglion cells in adult rats in vivo. Brain Res. 1993, 602, 304-317. [CrossRef]

61. Mansour-Robaey, S.; Clarke, D.B.; Wang, Y.C.; Bray, G.M.; Aguayo, A.J. Effects of ocular injury and administration of brain-derived neurotrophic factor on survival and regrowth of axotomized retinal ganglion cells. Proc. Natl. Acad. Sci. USA 1994, 91, 1632-1636. [CrossRef]

62. Peinado-Ramon, P.; Salvador, M.; Villegas-Perez, M.P.; Vidal-Sanz, M. Effects of axotomy and intraocular administration of NT-4, NT-3, and brain-derived neurotrophic factor on the survival of adult rat retinal ganglion cells. A quantitative in vivo study. Investig. Ophthalmol. Vis. Sci. 1996, 37, 489-500.

63. Domenici, L.; Origlia, N.; Falsini, B.; Cerri, E.; Barloscio, D.; Fabiani, C.; Sanso, M.; Giovannini, L. Rescue of retinal function by BDNF in a mouse model of glaucoma. PLoS ONE 2014, 9, e115579. [CrossRef] [PubMed]

64. Galindo-Romero, C.; Valiente-Soriano, F.J.; Jimenez-Lopez, M.; Garcia-Ayuso, D.; Villegas-Perez, M.P.; Vidal-Sanz, M.; Agudo-Barriuso, M. Effect of brain-derived neurotrophic factor on mouse axotomized retinal ganglion cells and phagocytic microglia. Investig. Ophthalmol. Vis. Sci. 2013, 54, 974-985. [CrossRef] [PubMed] 
65. Zhang, C.-W.; Lu, Q.; You, S.-W.; Zhi, Y.; Yip, H.K.; Wu, W.; So, K.-F.; Cui, Q. CNTF and BDNF have similar effects on retinal ganglion cell survival but differential effects on nitric oxide synthase expression soon after optic nerve injury. Investig. Opthalmol. Vis. Sci. 2005, 46, 1497. [CrossRef]

66. Meyer-Franke, A.; Kaplan, M.R.; Pfrieger, F.W.; Barres, B.A. Characterization of the signaling interactions that promote the survival and growth of developing retinal ganglion cells in culture. Neuron 1995, 15, 805-819. [CrossRef]

67. Leaver, S.G.; Cui, Q.; Plant, G.W.; Arulpragasam, A.; Hisheh, S.; Verhaagen, J.; Harvey, A.R. AAV-mediated expression of CNTF promotes long-term survival and regeneration of adult rat retinal ganglion cells. Gene Ther. 2006, 13, 1328-1341. [CrossRef]

68. Muller, A.; Hauk, T.G.; Leibinger, M.; Marienfeld, R.; Fischer, D. Exogenous CNTF stimulates axon regeneration of retinal ganglion cells partially via endogenous CNTF. Mol. Cell. Neurosci. 2009, 41, 233-246. [CrossRef]

69. Maffei, L.; Carmignoto, G.; Perry, V.H.; Candeo, P.; Ferrari, G. Schwann cells promote the survival of rat retinal ganglion cells after optic nerve section. Proc. Natl. Acad. Sci. USA 1990, 87, 1855-1859. [CrossRef]

70. Carmignoto, G.; Maffei, L.; Candeo, P.; Canella, R.; Comelli, C. Effect of NGF on the survival of rat retinal ganglion cells following optic nerve section. J. Neurosci. Off. J. Soc. Neurosci. 1989, 9, 1263-1272. [CrossRef]

71. Morgan, J.E. Retina ganglion cell degeneration in glaucoma: An opportunity missed? A review. Clin. Exp. Ophthalmol. 2012, 40, 364-368. [CrossRef]

72. Aires, I.D.; Ambrosio, A.F.; Santiago, A.R. Modeling human glaucoma: Lessons from the in vitro models. Ophthalmic Res. 2017, 57, 77-86. [CrossRef] [PubMed]

73. Wu, J.; Mak, H.K.; Chan, Y.K.; Lin, C.; Kong, C.; Leung, C.K.S.; Shum, H.C. An in vitro pressure model towards studying the response of primary retinal ganglion cells to elevated hydrostatic pressures. Sci. Rep. 2019, 9, 9057. [CrossRef] [PubMed]

74. Quigley, H.A.; Guy, J.; Anderson, D.R. Blockade of rapid axonal transport. Effect of intraocular pressure elevation in primate optic nerve. Arch. Ophthalmol. 1979, 97, 525-531. [CrossRef]

75. Quigley, H.A.; McKinnon, S.J.; Zack, D.J.; Pease, M.E.; Kerrigan-Baumrind, L.A.; Kerrigan, D.F.; Mitchell, R.S. Retrograde axonal transport of BDNF in retinal ganglion cells is blocked by acute IOP elevation in rats. Investig. Ophthalmol. Vis. Sci. 2000, 41, 3460-3466.

76. Pease, M.E.; McKinnon, S.J.; Quigley, H.A.; Kerrigan-Baumrind, L.A.; Zack, D.J. Obstructed axonal transport of BDNF and its receptor TrkB in experimental glaucoma. Investig. Ophthalmol. Vis. Sci. 2000, 41, 764-774.

77. Park, H.L.; Kim, S.W.; Kim, J.H.; Park, C.K. Increased levels of synaptic proteins involved in synaptic plasticity after chronic intraocular pressure elevation and modulation by brain-derived neurotrophic factor in a glaucoma animal model. Dis. Models Mech. 2019, 12. [CrossRef]

78. Aires, I.D.; Boia, R.; Rodrigues-Neves, A.C.; Madeira, M.H.; Marques, C.; Ambrosio, A.F.; Santiago, A.R. Blockade of microglial adenosine A2A receptor suppresses elevated pressure-induced inflammation, oxidative stress, and cell death in retinal cells. Glia 2019, 67, 896-914. [CrossRef]

79. Madeira, M.H.; Elvas, F.; Boia, R.; Goncalves, F.Q.; Cunha, R.A.; Ambrosio, A.F.; Santiago, A.R. Adenosine A2AR blockade prevents neuroinflammation-induced death of retinal ganglion cells caused by elevated pressure. J. Neuroinflamm. 2015, 12, 115. [CrossRef]

80. Harada, T.; Harada, C.; Parada, L.F. Molecular regulation of visual system development: More than meets the eye. Genes Dev. 2007, 21, 367-378. [CrossRef]

81. Kimura, A.; Namekata, K.; Guo, X.; Harada, C.; Harada, T. Neuroprotection, growth factors and BDNF-TrkB signalling in retinal degeneration. Int. J. Mol. Sci. 2016, 17, 1584. [CrossRef]

82. Johnson, T.V.; Bull, N.D.; Martin, K.R. Neurotrophic factor delivery as a protective treatment for glaucoma. Exp. Eye Res. 2011, 93, 196-203. [CrossRef] [PubMed]

83. Guo, X.J.; Tian, X.S.; Ruan, Z.; Chen, Y.T.; Wu, L.; Gong, Q.; Wang, W.; Zhang, H.Y. Dysregulation of neurotrophic and inflammatory systems accompanied by decreased CREB signaling in ischemic rat retina. Exp. Eye Res. 2014, 125, 156-163. [CrossRef] [PubMed]

84. Johnson, E.C.; Deppmeier, L.M.; Wentzien, S.K.; Hsu, I.; Morrison, J.C. Chronology of optic nerve head and retinal responses to elevated intraocular pressure. Investig. Ophthalmol. Vis. Sci. 2000, 41, 431-442.

85. Pietrucha-Dutczak, M.; Amadio, M.; Govoni, S.; Lewin-Kowalik, J.; Smedowski, A. The Role of endogenous neuroprotective mechanisms in the prevention of retinal ganglion cells degeneration. Front. Neurosci. 2018, 12, 834. [CrossRef] 
86. Garcia, M.; Forster, V.; Hicks, D.; Vecino, E. In vivo expression of neurotrophins and neurotrophin receptors is conserved in adult porcine retina in vitro. Investig. Ophthalmol. Vis. Sci. 2003, 44, 4532-4541. [CrossRef]

87. Ruiz-Ederra, J.; Hitchcock, P.F.; Vecino, E. Two classes of astrocytes in the adult human and pig retina in terms of their expression of high affinity NGF receptor (TrkA). Neurosci. Lett. 2003, 337, 127-130. [CrossRef]

88. Vecino, E.; Caminos, E.; Becker, E.; Martín-Zanca, D.; Osborne, N.N. Expression of neurotrophins and their receptors within the glial cells of retina and optic nerve. In Understanding glial cells; Springer: Boston, MA, USA, 1998; pp. 149-166. [CrossRef]

89. Garcia, M.; Forster, V.; Hicks, D.; Vecino, E. Effects of muller glia on cell survival and neuritogenesis in adult porcine retina in vitro. Investig. Ophthalmol. Vis. Sci. 2002, 43, 3735-3743.

90. Freeman, R.S.; Burch, R.L.; Crowder, R.J.; Lomb, D.J.; Schoell, M.C.; Straub, J.A.; Xie, L. NGF deprivation-induced gene expression: After ten years, where do we stand? Prog. Brain Res. 2004, 146, 111-126. [CrossRef]

91. Lomb, D.J.; Desouza, L.A.; Franklin, J.L.; Freeman, R.S. Prolyl hydroxylase inhibitors depend on extracellular glucose and hypoxia-inducible factor (HIF)-2alpha to inhibit cell death caused by nerve growth factor (NGF) deprivation: Evidence that HIF-2alpha has a role in NGF-promoted survival of sympathetic neurons. Mol. Pharmacol. 2009, 75, 1198-1209. [CrossRef]

92. Roberti, G.; Mantelli, F.; Macchi, I.; Massaro-Giordano, M.; Centofanti, M. Nerve growth factor modulation of retinal ganglion cell physiology. J. Cell. Physiol. 2014, 229, 1130-1133. [CrossRef]

93. Colafrancesco, V.; Parisi, V.; Sposato, V.; Rossi, S.; Russo, M.A.; Coassin, M.; Lambiase, A.; Aloe, L. Ocular application of nerve growth factor protects degenerating retinal ganglion cells in a rat model of glaucoma. J. Glaucoma 2011, 20, 100-108. [CrossRef] [PubMed]

94. Aloe, L.; Rocco, M.L.; Balzamino, B.O.; Micera, A. Nerve growth factor: A focus on neuroscience and therapy. Curr. Neuropharmacol. 2015, 13, 294-303. [CrossRef] [PubMed]

95. Chen, Q.; Wang, H.; Liao, S.; Gao, Y.; Liao, R.; Little, P.J.; Xu, J.; Feng, Z.P.; Zheng, Y.; Zheng, W. Nerve growth factor protects retinal ganglion cells against injury induced by retinal ischemia-reperfusion in rats. Growth Factors 2015, 33, 149-159. [CrossRef] [PubMed]

96. Lambiase, A.; Aloe, L.; Centofanti, M.; Parisi, V.; Bao, S.N.; Mantelli, F.; Colafrancesco, V.; Manni, G.L.; Bucci, M.G.; Bonini, S.; et al. Experimental and clinical evidence of neuroprotection by nerve growth factor eye drops: Implications for glaucoma. Proc. Natl. Acad. Sci. USA 2009, 106, 13469-13474. [CrossRef]

97. Vecino, E.; Garcia-Crespo, D.; Garcia, M.; Martinez-Millan, L.; Sharma, S.C.; Carrascal, E. Rat retinal ganglion cells co-express brain derived neurotrophic factor (BDNF) and its receptor TrkB. Vis. Res. 2002, 42, 151-157. [CrossRef]

98. Pernet, V.; Di Polo, A. Synergistic action of brain-derived neurotrophic factor and lens injury promotes retinal ganglion cell survival, but leads to optic nerve dystrophy in vivo. Brain A J. Neurol. 2006, 129, 1014-1026. [CrossRef]

99. Pietrucha-Dutczak, M.; Smedowski, A.; Liu, X.; Matuszek, I.; Varjosalo, M.; Lewin-Kowalik, J. Candidate proteins from predegenerated nerve exert time-specific protection of retinal ganglion cells in glaucoma. Sci. Rep. 2017, 7, 14540. [CrossRef]

100. Bai, Y.; Xu, J.; Brahimi, F.; Zhuo, Y.; Sarunic, M.V.; Saragovi, H.U. An agonistic TrkB mAb causes sustained TrkB activation, delays RGC death, and protects the retinal structure in optic nerve axotomy and in glaucoma. Investig. Ophthalmol. Vis. Sci. 2010, 51, 4722-4731. [CrossRef]

101. Ghaffariyeh, A.; Honarpisheh, N.; Shakiba, Y.; Puyan, S.; Chamacham, T.; Zahedi, F.; Zarrineghbal, M. Brain-derived neurotrophic factor in patients with normal-tension glaucoma. Optometry 2009, 80, 635-638. [CrossRef]

102. Oddone, F.; Roberti, G.; Micera, A.; Busanello, A.; Bonini, S.; Quaranta, L.; Agnifili, L.; Manni, G. Exploring serum levels of brain derived neurotrophic factor and nerve growth factor across glaucoma stages. PLoS ONE 2017, 12, e0168565. [CrossRef]

103. Airaksinen, M.S.; Saarma, M. The GDNF family: Signalling, biological functions and therapeutic value. Nat. Rev. Neurosci. 2002, 3, 383-394. [CrossRef]

104. Koeberle, P.D.; Ball, A.K. Effects of GDNF on retinal ganglion cell survival following axotomy. Vis. Res. 1998, 38, 1505-1515. [CrossRef] 
105. Yan, Q.; Wang, J.; Matheson, C.R.; Urich, J.L. Glial cell line-derived neurotrophic factor (GDNF) promotes the survival of axotomized retinal ganglion cells in adult rats: Comparison to and combination with brain-derived neurotrophic factor (BDNF). J. Neurobiol. 1999, 38, 382-390. [CrossRef]

106. Kyhn, M.V.; Klassen, H.; Johansson, U.E.; Warfvinge, K.; Lavik, E.; Kiilgaard, J.F.; Prause, J.U.; Scherfig, E.; Young, M.; la Cour, M. Delayed administration of glial cell line-derived neurotrophic factor (GDNF) protects retinal ganglion cells in a pig model of acute retinal ischemia. Exp. Eye Res. 2009, 89, 1012-1020. [CrossRef] [PubMed]

107. Checa-Casalengua, P.; Jiang, C.; Bravo-Osuna, I.; Tucker, B.A.; Molina-Martinez, I.T.; Young, M.J.; Herrero-Vanrell, R. Retinal ganglion cells survival in a glaucoma model by GDNF/Vit E PLGA microspheres prepared according to a novel microencapsulation procedure. J. Control. Release Off. J. Control. Release Soc. 2011, 156, 92-100. [CrossRef] [PubMed]

108. Ward, M.S.; Khoobehi, A.; Lavik, E.B.; Langer, R.; Young, M.J. Neuroprotection of retinal ganglion cells in DBA/2J mice with GDNF-loaded biodegradable microspheres. J. Pharm. Sci. 2007, 96, 558-568. [CrossRef]

109. Koeberle, P.D.; Bahr, M. The upregulation of GLAST-1 is an indirect antiapoptotic mechanism of GDNF and neurturin in the adult CNS. Cell Death Differ. 2008, 15, 471-483. [CrossRef]

110. Del Rio, P.; Irmler, M.; Arango-Gonzalez, B.; Favor, J.; Bobe, C.; Bartsch, U.; Vecino, E.; Beckers, J.; Hauck, S.M.; Ueffing, M. GDNF-induced osteopontin from Muller glial cells promotes photoreceptor survival in the Pde6brd1 mouse model of retinal degeneration. Glia 2011, 59, 821-832. [CrossRef]

111. Ernst, M.; Jenkins, B.J. Acquiring signalling specificity from the cytokine receptor gp130. Trends Genet. TIG 2004, 20, 23-32. [CrossRef]

112. Kirsch, M.; Lee, M.Y.; Meyer, V.; Wiese, A.; Hofmann, H.D. Evidence for multiple, local functions of ciliary neurotrophic factor $(\mathrm{CNTF})$ in retinal development: Expression of CNTF and its receptors and in vitro effects on target cells. J. Neurochem. 1997, 68, 979-990. [CrossRef]

113. Wen, R.; Song, Y.; Liu, Y.; Li, Y.; Zhao, L.; Laties, A.M. CNTF negatively regulates the phototransduction machinery in rod photoreceptors: Implication for light-induced photostasis plasticity. Adv. Exp. Med. Biol. 2008, 613, 407-413. [CrossRef] [PubMed]

114. Mathews, M.K.; Guo, Y.; Langenberg, P.; Bernstein, S.L. Ciliary neurotrophic factor (CNTF)-mediated ganglion cell survival in a rodent model of non-arteritic anterior ischaemic optic neuropathy (NAION). Br. J. Ophthalmol. 2015, 99, 133-137. [CrossRef] [PubMed]

115. Pease, M.E.; Zack, D.J.; Berlinicke, C.; Bloom, K.; Cone, F.; Wang, Y.; Klein, R.L.; Hauswirth, W.W.; Quigley, H.A. Effect of CNTF on retinal ganglion cell survival in experimental glaucoma. Investig. Ophthalmol. Vis. Sci. 2009, 50, 2194-2200. [CrossRef] [PubMed]

116. Maier, K.; Rau, C.R.; Storch, M.K.; Sattler, M.B.; Demmer, I.; Weissert, R.; Taheri, N.; Kuhnert, A.V.; Bahr, M.; Diem, R. Ciliary neurotrophic factor protects retinal ganglion cells from secondary cell death during acute autoimmune optic neuritis in rats. Brain Pathol. 2004, 14, 378-387. [CrossRef]

117. Fischer, D.; Leibinger, M. Promoting optic nerve regeneration. Prog. Retin. Eye Res. 2012, 31, 688-701. [CrossRef]

118. Muller, A.; Hauk, T.G.; Fischer, D. Astrocyte-derived CNTF switches mature RGCs to a regenerative state following inflammatory stimulation. Brain A J. Neurol. 2007, 130, 3308-3320. [CrossRef]

119. Shpak, A.A.; Guekht, A.B.; Druzhkova, T.A.; Kozlova, K.I.; Gulyaeva, N.V. Ciliary neurotrophic factor in patients with primary open-angle glaucoma and age-related cataract. Mol. Vis. 2017, 23, 799-809.

120. Zhou, X.; Li, F.; Kong, L.; Chodosh, J.; Cao, W. Anti-inflammatory effect of pigment epithelium-derived factor in DBA/2J mice. Mol. Vis. 2009, 15, 438-450.

121. Yang, X.; Wei, A.; Liu, Y.; He, G.; Zhou, Z.; Yu, Z. IGF-1 protects retinal ganglion cells from hypoxia-induced apoptosis by activating the Erk-1/2 and Akt pathways. Mol. Vis. 2013, 19, 1901-1912.

122. Kermer, P.; Klocker, N.; Labes, M.; Bahr, M. Insulin-like growth factor-I protects axotomized rat retinal ganglion cells from secondary death via PI3-K-dependent Akt phosphorylation and inhibition of caspase-3 in vivo. J. Neurosci. Off. J. Soc. Neurosci. 2000, 20, 2-8. [CrossRef]

123. Foxton, R.H.; Finkelstein, A.; Vijay, S.; Dahlmann-Noor, A.; Khaw, P.T.; Morgan, J.E.; Shima, D.T.; Ng, Y.S. VEGF-A is necessary and sufficient for retinal neuroprotection in models of experimental glaucoma. Am. J. Pathol. 2013, 182, 1379-1390. [CrossRef] [PubMed]

124. Lv, B.; Wang, R.; Gao, X.; Dong, X.; Ji, X. Effect of vascular endothelial growth factor on retinal ganglion cells of rats with chronic intraocular hypertension. Int. J. Clin. Exp. Pathol. 2014, 7, 5717-5724. [PubMed] 
125. Brar, V.S.; Sharma, R.K.; Murthy, R.K.; Chalam, K.V. Bevacizumab neutralizes the protective effect of vascular endothelial growth factor on retinal ganglion cells. Mol. Vis. 2010, 16, 1848-1853. [PubMed]

126. Lee, W.J.; Kim, Y.K.; Kim, Y.W.; Jeoung, J.W.; Kim, S.H.; Heo, J.W.; Yu, H.G.; Park, K.H. Rate of macular ganglion cell-inner plexiform layer thinning in glaucomatous eyes with vascular endothelial growth factor inhibition. J. Glaucoma 2017, 26, 980-986. [CrossRef] [PubMed]

127. Sisk, D.R.; Kuwabara, T. Histologic changes in the inner retina of albino rats following intravitreal injection of monosodium L-glutamate. Graefes Arch. Clin. Exp. Ophthalmol. 1985, 223, 250-258. [CrossRef]

128. Sucher, N.J.; Lipton, S.A.; Dreyer, E.B. Molecular basis of glutamate toxicity in retinal ganglion cells. Vis. Res. 1997, 37, 3483-3493. [CrossRef]

129. Vorwerk, C.K.; Lipton, S.A.; Zurakowski, D.; Hyman, B.T.; Sabel, B.A.; Dreyer, E.B. Chronic low-dose glutamate is toxic to retinal ganglion cells. Toxicity blocked by memantine. Investig. Ophthalmol. Vis. Sci. 1996, 37, 1618-1624.

130. Dreyer, E.B.; Zurakowski, D.; Schumer, R.A.; Podos, S.M.; Lipton, S.A. Elevated glutamate levels in the vitreous body of humans and monkeys with glaucoma. Arch. Ophthalmol. 1996, 114, 299-305. [CrossRef]

131. Brooks, D.E.; Garcia, G.A.; Dreyer, E.B.; Zurakowski, D.; Franco-Bourland, R.E. Vitreous body glutamate concentration in dogs with glaucoma. Am. J. Vet. Res. 1997, 58, 864-867.

132. Chaudhary, P.; Ahmed, F.; Sharma, S.C. MK801-a neuroprotectant in rat hypertensive eyes. Brain Res. 1998, 792, 154-158. [CrossRef]

133. Guo, L.; Salt, T.E.; Maass, A.; Luong, V.; Moss, S.E.; Fitzke, F.W.; Cordeiro, M.F. Assessment of neuroprotective effects of glutamate modulation on glaucoma-related retinal ganglion cell apoptosis in vivo. Investig. Ophthalmol. Vis. Sci. 2006, 47, 626-633. [CrossRef] [PubMed]

134. Lipton, S.A. Prospects for clinically tolerated NMDA antagonists: Open-channel blockers and alternative redox states of nitric oxide. Trends Neurosci. 1993, 16, 527-532. [CrossRef]

135. Lagreze, W.A.; Knorle, R.; Bach, M.; Feuerstein, T.J. Memantine is neuroprotective in a rat model of pressure-induced retinal ischemia. Investig. Ophthalmol. Vis. Sci. 1998, 39, 1063-1066.

136. Hare, W.A.; WoldeMussie, E.; Lai, R.K.; Ton, H.; Ruiz, G.; Chun, T.; Wheeler, L. Efficacy and safety of memantine treatment for reduction of changes associated with experimental glaucoma in monkey, I: Functional measures. Investig. Ophthalmol. Vis. Sci. 2004, 45, 2625-2639. [CrossRef] [PubMed]

137. Danesh-Meyer, H.V.; Levin, L.A. Neuroprotection: Extrapolating from neurologic diseases to the eye. Am. J. Ophthalmol. 2009, 148, 186-191.e2. [CrossRef] [PubMed]

138. Wheeler, L.A.; Gil, D.W.; WoldeMussie, E. Role of alpha-2 adrenergic receptors in neuroprotection and glaucoma. Surv. Ophthalmol. 2001, 45 (Suppl. 3), S290-S294, discussion S295-S296. [CrossRef]

139. Hernandez, M.; Urcola, J.H.; Vecino, E. Retinal ganglion cell neuroprotection in a rat model of glaucoma following brimonidine, latanoprost or combined treatments. Exp. Eye Res. 2008, 86, 798-806. [CrossRef]

140. Pinar-Sueiro, S.; Urcola, H.; Rivas, M.A.; Vecino, E. Prevention of retinal ganglion cell swelling by systemic brimonidine in a rat experimental glaucoma model. Clin. Exp. Ophthalmol. 2011, 39, 799-807. [CrossRef]

141. Ahmed, F.A.; Hegazy, K.; Chaudhary, P.; Sharma, S.C. Neuroprotective effect of alpha(2) agonist (brimonidine) on adult rat retinal ganglion cells after increased intraocular pressure. Brain Res. 2001, 913, 133-139. [CrossRef]

142. Yoles, E.; Wheeler, L.A.; Schwartz, M. Alpha2-adrenoreceptor agonists are neuroprotective in a rat model of optic nerve degeneration. Investig. Ophthalmol. Vis. Sci. 1999, 40, 65-73.

143. Donello, J.E.; Padillo, E.U.; Webster, M.L.; Wheeler, L.A.; Gil, D.W. alpha(2)-Adrenoceptor agonists inhibit vitreal glutamate and aspartate accumulation and preserve retinal function after transient ischemia. J. Pharmacol. Exp. Ther. 2001, 296, 216-223. [PubMed]

144. Kalapesi, F.B.; Coroneo, M.T.; Hill, M.A. Human ganglion cells express the alpha-2 adrenergic receptor: Relevance to neuroprotection. Br. J. Ophthalmol. 2005, 89, 758-763. [CrossRef] [PubMed]

145. Aung, T.; Oen, F.T.; Wong, H.T.; Chan, Y.H.; Khoo, B.K.; Liu, Y.P.; Ho, C.L.; See, J.; Thean, L.H.; Viswanathan, A.C.; et al. Randomised controlled trial comparing the effect of brimonidine and timolol on visual field loss after acute primary angle closure. Br. J. Ophthalmol. 2004, 88, 88-94. [CrossRef] [PubMed]

146. Lambert, W.S.; Ruiz, L.; Crish, S.D.; Wheeler, L.A.; Calkins, D.J. Brimonidine prevents axonal and somatic degeneration of retinal ganglion cell neurons. Mol. Neurodegener. 2011, 6, 4. [CrossRef]

147. Tsai, J.C.; Chang, H.W. Comparison of the effects of brimonidine $0.2 \%$ and timolol $0.5 \%$ on retinal nerve fiber layer thickness in ocular hypertensive patients: A prospective, unmasked study. J. Ocul. Pharmacol. Ther. 2005, 21, 475-482. [CrossRef] 
148. Doozandeh, A.; Yazdani, S. Neuroprotection in glaucoma. J. Ophthalmic Vis. Res. 2016, 11, 209-220. [CrossRef]

149. Crish, S.D.; Calkins, D.J. Neurodegeneration in glaucoma: Progression and calcium-dependent intracellular mechanisms. Neuroscience 2011, 176, 1-11. [CrossRef]

150. Stout, A.K.; Raphael, H.M.; Kanterewicz, B.I.; Klann, E.; Reynolds, I.J. Glutamate-induced neuron death requires mitochondrial calcium uptake. Nat. Neurosci. 1998, 1, 366-373. [CrossRef]

151. Osborne, N.N.; Wood, J.P.; Cupido, A.; Melena, J.; Chidlow, G. Topical flunarizine reduces IOP and protects the retina against ischemia-excitotoxicity. Investig. Ophthalmol. Vis. Sci. 2002, 43, 1456-1464.

152. Yamada, H.; Chen, Y.N.; Aihara, M.; Araie, M. Neuroprotective effect of calcium channel blocker against retinal ganglion cell damage under hypoxia. Brain Res. 2006, 1071, 75-80. [CrossRef]

153. Koseki, N.; Araie, M.; Tomidokoro, A.; Nagahara, M.; Hasegawa, T.; Tamaki, Y.; Yamamoto, S. A placebo-controlled 3-year study of a calcium blocker on visual field and ocular circulation in glaucoma with low-normal pressure. Ophthalmology 2008, 115, 2049-2057. [CrossRef] [PubMed]

154. Mayama, C. Calcium channels and their blockers in intraocular pressure and glaucoma. Eur. J. Pharmacol. 2014, 739, 96-105. [CrossRef] [PubMed]

155. Izzotti, A.; Bagnis, A.; Sacca, S.C. The role of oxidative stress in glaucoma. Mutat. Res. 2006, 612, 105-114. [CrossRef] [PubMed]

156. Geiger, L.K.; Kortuem, K.R.; Alexejun, C.; Levin, L.A. Reduced redox state allows prolonged survival of axotomized neonatal retinal ganglion cells. Neuroscience 2002, 109, 635-642. [CrossRef]

157. Caprioli, J.; Munemasa, Y.; Kwong, J.M.; Piri, N. Overexpression of thioredoxins 1 and 2 increases retinal ganglion cell survival after pharmacologically induced oxidative stress, optic nerve transection, and in experimental glaucoma. Trans. Am. Ophthalmol. Soc. 2009, 107, 161-165.

158. Swanson, K.I.; Schlieve, C.R.; Lieven, C.J.; Levin, L.A. Neuroprotective effect of sulfhydryl reduction in a rat optic nerve crush model. Investig. Ophthalmol. Vis. Sci. 2005, 46, 3737-3741. [CrossRef]

159. Nucci, C.; Tartaglione, R.; Cerulli, A.; Mancino, R.; Spano, A.; Cavaliere, F.; Rombola, L.; Bagetta, G.; Corasaniti, M.T.; Morrone, L.A. Retinal damage caused by high intraocular pressure-induced transient ischemia is prevented by coenzyme Q10 in rat. Int. Rev. Neurobiol. 2007, 82, 397-406. [CrossRef]

160. Russo, R.; Cavaliere, F.; Rombola, L.; Gliozzi, M.; Cerulli, A.; Nucci, C.; Fazzi, E.; Bagetta, G.; Corasaniti, M.T.; Morrone, L.A. Rational basis for the development of coenzyme Q10 as a neurotherapeutic agent for retinal protection. Prog. Brain Res. 2008, 173, 575-582. [CrossRef]

161. Nakajima, Y.; Inokuchi, Y.; Nishi, M.; Shimazawa, M.; Otsubo, K.; Hara, H. Coenzyme Q10 protects retinal cells against oxidative stress in vitro and in vivo. Brain Res. 2008, 1226, 226-233. [CrossRef]

162. Pinar-Sueiro, S.; Martinez-Fernandez, R.; Lage-Medina, S.; Aldamiz-Echevarria, L.; Vecino, E. Optic neuropathy in methylmalonic acidemia: The role of neuroprotection. J. Inherit. Metab. Dis. 2010, 33 (Suppl. 3), S199-S203. [CrossRef]

163. Gherghel, D.; Griffiths, H.R.; Hilton, E.J.; Cunliffe, I.A.; Hosking, S.L. Systemic reduction in glutathione levels occurs in patients with primary open-angle glaucoma. Investig. Ophthalmol. Vis. Sci. 2005, 46, 877-883. [CrossRef]

164. Aydemir, O.; Naziroglu, M.; Celebi, S.; Yilmaz, T.; Kukner, A.S. Antioxidant effects of alpha-, gamma- and succinate-tocopherols in guinea pig retina during ischemia-reperfusion injury. Pathophysiol. Off. J. Int. Soc. Pathophysiol. 2004, 11, 167-171. [CrossRef]

165. Dilsiz, N.; Sahaboglu, A.; Yildiz, M.Z.; Reichenbach, A. Protective effects of various antioxidants during ischemia-reperfusion in the rat retina. Graefes Arch. Clin. Exp. Ophthalmol. 2006, 244, 627-633. [CrossRef]

166. Ko, M.L.; Peng, P.H.; Hsu, S.Y.; Chen, C.F. Dietary deficiency of vitamin E aggravates retinal ganglion cell death in experimental glaucoma of rats. Curr. Eye Res. 2010, 35, 842-849. [CrossRef] [PubMed]

167. Liu, L.; Sun, Q.; Wang, R.; Chen, Z.; Wu, J.; Xia, F.; Fan, X.Q. Methane attenuates retinal ischemia/reperfusion injury via anti-oxidative and anti-apoptotic pathways. Brain Res. 2016, 1646, 327-333. [CrossRef] [PubMed]

168. Schultz, R.; Witte, O.W.; Schmeer, C. Increased frataxin levels protect retinal ganglion cells after acute ischemia/reperfusion in the mouse retina in vivo. Investig. Ophthalmol. Vis. Sci. 2016, 57, 4115-4124. [CrossRef] [PubMed]

169. Chen, L.; Qi, Y.; Yang, X. Neuroprotective effects of crocin against oxidative stress induced by ischemia/reperfusion injury in rat retina. Ophthalmic Res. 2015, 54, 157-168. [CrossRef]

170. Nebbioso, M.; Scarsella, G.; Tafani, M.; Pescosolido, N. Mechanisms of ocular neuroprotection by antioxidant molecules in animal models. J. Biol. Regul. Homeost. Agents 2013, 27, 197-209. 
171. Jiang, W.; Tang, L.; Zeng, J.; Chen, B. Adeno-associated virus mediated SOD gene therapy protects the retinal ganglion cells from chronic intraocular pressure elevation induced injury via attenuating oxidative stress and improving mitochondrial dysfunction in a rat model. Am. J. Transl. Res. 2016, 8, 799-810.

172. Park, S.H.; Kim, J.H.; Kim, Y.H.; Park, C.K. Expression of neuronal nitric oxide synthase in the retina of a rat model of chronic glaucoma. Vis. Res. 2007, 47, 2732-2740. [CrossRef]

173. Aslan, M.; Cort, A.; Yucel, I. Oxidative and nitrative stress markers in glaucoma. Free Radic. Biol. Med. 2008, 45, 367-376. [CrossRef] [PubMed]

174. Siu, A.W.; Leung, M.C.; To, C.H.; Siu, F.K.; Ji, J.Z.; So, K.F. Total retinal nitric oxide production is increased in intraocular pressure-elevated rats. Exp. Eye Res. 2002, 75, 401-406. [CrossRef] [PubMed]

175. Shareef, S.; Sawada, A.; Neufeld, A.H. Isoforms of nitric oxide synthase in the optic nerves of rat eyes with chronic moderately elevated intraocular pressure. Investig. Ophthalmol. Vis. Sci. 1999, 40, 2884-2891.

176. Hangai, M.; Yoshimura, N.; Hiroi, K.; Mandai, M.; Honda, Y. Inducible nitric oxide synthase in retinal ischemia-reperfusion injury. Exp. Eye Res. 1996, 63, 501-509. [CrossRef] [PubMed]

177. Neufeld, A.H.; Kawai, S.; Das, S.; Vora, S.; Gachie, E.; Connor, J.R.; Manning, P.T. Loss of retinal ganglion cells following retinal ischemia: The role of inducible nitric oxide synthase. Exp. Eye Res. 2002, 75, 521-528. [CrossRef] [PubMed]

178. Liu, B.; Neufeld, A.H. Expression of nitric oxide synthase-2 (NOS-2) in reactive astrocytes of the human glaucomatous optic nerve head. Glia 2000, 30, 178-186. [CrossRef]

179. Neufeld, A.H.; Hernandez, M.R.; Gonzalez, M. Nitric oxide synthase in the human glaucomatous optic nerve head. Arch. Ophthalmol. 1997, 115, 497-503. [CrossRef]

180. Neufeld, A.H.; Sawada, A.; Becker, B. Inhibition of nitric-oxide synthase 2 by aminoguanidine provides neuroprotection of retinal ganglion cells in a rat model of chronic glaucoma. Proc. Natl. Acad. Sci. USA 1999, 96, 9944-9948. [CrossRef]

181. Geyer, O.; Almog, J.; Lupu-Meiri, M.; Lazar, M.; Oron, Y. Nitric oxide synthase inhibitors protect rat retina against ischemic injury. FEBS Lett. 1995, 374, 399-402. [CrossRef]

182. Libby, R.T.; Howell, G.R.; Pang, I.H.; Savinova, O.V.; Mehalow, A.K.; Barter, J.W.; Smith, R.S.; Clark, A.F.; John, S.W. Inducible nitric oxide synthase, Nos2, does not mediate optic neuropathy and retinopathy in the DBA/2J glaucoma model. BMC Neurosci. 2007, 8, 108. [CrossRef]

183. Pang, I.H.; Johnson, E.C.; Jia, L.; Cepurna, W.O.; Shepard, A.R.; Hellberg, M.R.; Clark, A.F.; Morrison, J.C. Evaluation of inducible nitric oxide synthase in glaucomatous optic neuropathy and pressure-induced optic nerve damage. Investig. Ophthalmol. Vis. Sci. 2005, 46, 1313-1321. [CrossRef] [PubMed]

184. Oku, H.; Goto, W.; Kobayashi, T.; Okuno, T.; Hirao, M.; Sugiyama, T.; Yoneda, S.; Hara, H.; Ikeda, T. Adenosine protects cultured retinal neurons against NMDA-induced cell death through A1 receptors. Curr. Eye Res. 2004, 29, 449-455. [CrossRef] [PubMed]

185. Sun, X.; Barnes, S.; Baldridge, W.H. Adenosine inhibits calcium channel currents via A1 receptors on salamander retinal ganglion cells in a mini-slice preparation. J. Neurochem. 2002, 81, 550-556. [CrossRef] [PubMed]

186. Larsen, A.K.; Osborne, N.N. Involvement of adenosine in retinal ischemia. Studies on the rat. Investig. Ophthalmol. Vis. Sci. 1996, 37, 2603-2611.

187. Perigolo-Vicente, R.; Ritt, K.; Pereira, M.R.; Torres, P.M.; Paes-de-Carvalho, R.; Giestal-de-Araujo, E. IL-6 treatment increases the survival of retinal ganglion cells in vitro: The role of adenosine A1 receptor. Biochem. Biophys. Res. Commun. 2013, 430, 512-518. [CrossRef]

188. Mendonca Torres, P.M.; de Araujo, E.G. Interleukin-6 increases the survival of retinal ganglion cells in vitro. J. Neuroimmunol. 2001, 117, 43-50. [CrossRef]

189. Sappington, R.M.; Chan, M.; Calkins, D.J. Interleukin-6 protects retinal ganglion cells from pressure-induced death. Investig. Ophthalmol. Vis. Sci. 2006, 47, 2932-2942. [CrossRef]

190. Murphy, P.G.; Borthwick, L.A.; Altares, M.; Gauldie, J.; Kaplan, D.; Richardson, P.M. Reciprocal actions of interleukin-6 and brain-derived neurotrophic factor on rat and mouse primary sensory neurons. Eur. J. Neurosci. 2000, 12, 1891-1899. [CrossRef]

191. Mailavaram, R.P.; Al-Attraqchi, O.H.A.; Kar, S.; Ghosh, S. Current status in the design and development of agonists and antagonists of adenosine A3 receptor as potential therapeutic agents. Curr. Pharm. Des. 2019, 25, 2772-2787. [CrossRef] 
192. Zhang, M.; Budak, M.T.; Lu, W.; Khurana, T.S.; Zhang, X.; Laties, A.M.; Mitchell, C.H. Identification of the A3 adenosine receptor in rat retinal ganglion cells. Mol. Vis. 2006, 12, 937-948.

193. Hu, H.; Lu, W.; Zhang, M.; Zhang, X.; Argall, A.J.; Patel, S.; Lee, G.E.; Kim, Y.C.; Jacobson, K.A.; Laties, A.M.; et al. Stimulation of the P2X7 receptor kills rat retinal ganglion cells in vivo. Exp. Eye Res. 2010, 91, 425-432. [CrossRef] [PubMed]

194. Zhang, X.; Zhang, M.; Laties, A.M.; Mitchell, C.H. Balance of purines may determine life or death of retinal ganglion cells as A3 adenosine receptors prevent loss following P2X7 receptor stimulation. J. Neurochem. 2006, 98, 566-575. [CrossRef] [PubMed]

195. Zhang, M.; Hu, H.; Zhang, X.; Lu, W.; Lim, J.; Eysteinsson, T.; Jacobson, K.A.; Laties, A.M.; Mitchell, C.H. The A3 adenosine receptor attenuates the calcium rise triggered by NMDA receptors in retinal ganglion cells. Neurochem. Int. 2010, 56, 35-41. [CrossRef] [PubMed]

196. Nakashima, K.I.; Iwao, K.; Inoue, T.; Haga, A.; Tsutsumi, T.; Mochita, M.I.; Fujimoto, T.; Tanihara, H. Stimulation of the adenosine A3 receptor, not the A1 or A2 receptors, promote neurite outgrowth of retinal ganglion cells. Exp. Eye Res. 2018, 170, 160-168. [CrossRef]

197. Galvao, J.; Elvas, F.; Martins, T.; Cordeiro, M.F.; Ambrosio, A.F.; Santiago, A.R. Adenosine A3 receptor activation is neuroprotective against retinal neurodegeneration. Exp. Eye Res. 2015, 140, 65-74. [CrossRef]

198. Cen, L.P.; Ng, T.K. Stem cell therapy for retinal ganglion cell degeneration. Neural Regen. Res. 2018, 13, 1352-1353. [CrossRef]

199. Bennicelli, J.L.; Bennett, J. Stem cells set their sights on retinitis pigmentosa. eLife 2013, 2, e01291. [CrossRef]

200. Siqueira, R.C. Stem cell therapy for retinal diseases: Update. Stem Cell Res. Ther. 2011, 2, 50. [CrossRef]

201. Zarbin, M. Cell-based therapy for degenerative retinal disease. Trends Mol. Med. 2016, 22, 115-134. [CrossRef]

202. Eiraku, M.; Takata, N.; Ishibashi, H.; Kawada, M.; Sakakura, E.; Okuda, S.; Sekiguchi, K.; Adachi, T.; Sasai, Y. Self-organizing optic-cup morphogenesis in three-dimensional culture. Nature 2011, 472, 51-56. [CrossRef]

203. Nakano, T.; Ando, S.; Takata, N.; Kawada, M.; Muguruma, K.; Sekiguchi, K.; Saito, K.; Yonemura, S.; Eiraku, M.; Sasai, Y. Self-formation of optic cups and storable stratified neural retina from human ESCs. Cell Stem Cell 2012, 10, 771-785. [CrossRef] [PubMed]

204. Eiraku, M.; Sasai, Y. Mouse embryonic stem cell culture for generation of three-dimensional retinal and cortical tissues. Nat. Protoc. 2011, 7, 69-79. [CrossRef] [PubMed]

205. Mead, B.; Berry, M.; Logan, A.; Scott, R.A.; Leadbeater, W.; Scheven, B.A. Stem cell treatment of degenerative eye disease. Stem Cell Res. 2015, 14, 243-257. [CrossRef] [PubMed]

206. Hankin, M.H.; Lund, R.D. Directed early axonal outgrowth from retinal transplants into host rat brains. J. Neurobiol. 1990, 21, 1202-1218. [CrossRef] [PubMed]

207. Lund, R.D.; Hankin, M.H. Pathfinding by retinal ganglion cell axons: Transplantation studies in genetically and surgically blind mice. J. Comp. Neurol. 1995, 356, 481-489. [CrossRef]

208. Hertz, J.; Qu, B.; Hu, Y.; Patel, R.D.; Valenzuela, D.A.; Goldberg, J.L. Survival and integration of developing and progenitor-derived retinal ganglion cells following transplantation. Cell Transplant. 2014, 23, 855-872. [CrossRef]

209. Venugopalan, P.; Wang, Y.; Nguyen, T.; Huang, A.; Muller, K.J.; Goldberg, J.L. Transplanted neurons integrate into adult retinas and respond to light. Nat. Commun. 2016, 7, 10472. [CrossRef]

210. Tang, R.; Jing, L.; Willard, V.P.; Wu, C.L.; Guilak, F.; Chen, J.; Setton, L.A. Differentiation of human induced pluripotent stem cells into nucleus pulposus-like cells. Stem Cell Res. Ther. 2018, 9, 61. [CrossRef]

211. Razavi, S.; Razavi, M.R.; Zarkesh Esfahani, H.; Kazemi, M.; Mostafavi, F.S. Comparing brain-derived neurotrophic factor and ciliary neurotrophic factor secretion of induced neurotrophic factor secreting cells from human adipose and bone marrow-derived stem cells. Dev. Growth Differ. 2013, 55, 648-655. [CrossRef]

212. Hu, Y.; Tan, H.B.; Wang, X.M.; Rong, H.; Cui, H.P.; Cui, H. Bone marrow mesenchymal stem cells protect against retinal ganglion cell loss in aged rats with glaucoma. Clin. Interv. Aging 2013, 8, 1467-1470. [CrossRef]

213. Osborne, A.; Sanderson, J.; Martin, K.R. Neuroprotective Effects of Human Mesenchymal Stem Cells and Platelet-Derived Growth Factor on Human Retinal Ganglion Cells. Stem Cells 2018, 36, 65-78. [CrossRef]

214. Mead, B.; Amaral, J.; Tomarev, S. Mesenchymal stem cell-derived small extracellular vesicles promote neuroprotection in rodent models of glaucoma. Investig. Ophthalmol. Vis. Sci. 2018, 59, 702-714. [CrossRef]

215. Sochocka, M.; Diniz, B.S.; Leszek, J. Inflammatory response in the CNS: Friend or foe? Mol. Neurobiol. 2017, 54, 8071-8089. [CrossRef] 
216. Kreutzberg, G.W. Microglia: A sensor for pathological events in the CNS. Trends Neurosci. 1996, 19, 312-318. [CrossRef]

217. O'Callaghan, J.P.; Sriram, K. Glial fibrillary acidic protein and related glial proteins as biomarkers of neurotoxicity. Expert Opin. Drug Saf. 2005, 4, 433-442. [CrossRef]

218. Silverman, S.M.; Wong, W.T. Microglia in the retina: Roles in development, maturity, and disease. Ann. Rev. Vis. Sci. 2018, 4, 45-77. [CrossRef]

219. Karlstetter, M.; Ebert, S.; Langmann, T. Microglia in the healthy and degenerating retina: Insights from novel mouse models. Immunobiology 2010, 215, 685-691. [CrossRef]

220. Karlstetter, M.; Langmann, T. Microglia in the aging retina. Adv. Exp. Med. Biol. 2014, 801, $207-212$. [CrossRef]

221. Rashid, K.; Akhtar-Schaefer, I.; Langmann, T. Microglia in retinal degeneration. Front. Immunol. 2019, 10, 1975. [CrossRef]

222. Takeda, A.; Shinozaki, Y.; Kashiwagi, K.; Ohno, N.; Eto, K.; Wake, H.; Nabekura, J.; Koizumi, S. Microglia mediate non-cell-autonomous cell death of retinal ganglion cells. Glia 2018, 66, 2366-2384. [CrossRef]

223. Ullian, E.M.; Barkis, W.B.; Chen, S.; Diamond, J.S.; Barres, B.A. Invulnerability of retinal ganglion cells to NMDA excitotoxicity. Mol. Cell. Neurosci. 2004, 26, 544-557. [CrossRef]

224. Neufeld, A.H. Microglia in the optic nerve head and the region of parapapillary chorioretinal atrophy in glaucoma. Arch. Ophthalmol. 1999, 117, 1050-1056. [CrossRef]

225. Yuan, L.; Neufeld, A.H. Activated microglia in the human glaucomatous optic nerve head. J. Neurosci. Res. 2001, 64, 523-532. [CrossRef]

226. Bosco, A.; Steele, M.R.; Vetter, M.L. Early microglia activation in a mouse model of chronic glaucoma. J. Comp. Neurol. 2011, 519, 599-620. [CrossRef]

227. Bosco, A.; Romero, C.O.; Breen, K.T.; Chagovetz, A.A.; Steele, M.R.; Ambati, B.K.; Vetter, M.L. Neurodegeneration severity can be predicted from early microglia alterations monitored in vivo in a mouse model of chronic glaucoma. Dis. Models Mech. 2015, 8, 443-455. [CrossRef]

228. Madeira, M.H.; Boia, R.; Elvas, F.; Martins, T.; Cunha, R.A.; Ambrosio, A.F.; Santiago, A.R. Selective A2A receptor antagonist prevents microglia-mediated neuroinflammation and protects retinal ganglion cells from high intraocular pressure-induced transient ischemic injury. Transl. Res. J. Lab. Clin. Med. 2016, 169, 112-128. [CrossRef]

229. Cho, K.J.; Kim, J.H.; Park, H.Y.; Park, C.K. Glial cell response and iNOS expression in the optic nerve head and retina of the rat following acute high IOP ischemia-reperfusion. Brain Res. 2011, 1403, 67-77. [CrossRef]

230. Madeira, M.H.; Ortin-Martinez, A.; Nadal-Nicolas, F.; Ambrosio, A.F.; Vidal-Sanz, M.; Agudo-Barriuso, M.; Santiago, A.R. Caffeine administration prevents retinal neuroinflammation and loss of retinal ganglion cells in an animal model of glaucoma. Sci. Rep. 2016, 6, 27532. [CrossRef]

231. Rodrigues-Neves, A.C.; Aires, I.D.; Vindeirinho, J.; Boia, R.; Madeira, M.H.; Goncalves, F.Q.; Cunha, R.A.; Santos, P.F.; Ambrosio, A.F.; Santiago, A.R. Elevated Pressure Changes the Purinergic System of Microglial Cells. Front. Pharmacol. 2018, 9, 16. [CrossRef]

232. Davalos, D.; Grutzendler, J.; Yang, G.; Kim, J.V.; Zuo, Y.; Jung, S.; Littman, D.R.; Dustin, M.L.; Gan, W.B. ATP mediates rapid microglial response to local brain injury in vivo. Nat. Neurosci. 2005, 8, 752-758. [CrossRef]

233. Santiago, A.R.; Baptista, F.I.; Santos, P.F.; Cristovao, G.; Ambrosio, A.F.; Cunha, R.A.; Gomes, C.A. Role of microglia adenosine $\mathrm{A}(2 \mathrm{~A})$ receptors in retinal and brain neurodegenerative diseases. Mediat. Inflamm. 2014, 2014, 465694. [CrossRef]

234. Boia, R.; Elvas, F.; Madeira, M.H.; Aires, I.D.; Rodrigues-Neves, A.C.; Tralhao, P.; Szabo, E.C.; Baqi, Y.; Muller, C.E.; Tome, A.R.; et al. Treatment with A2A receptor antagonist KW6002 and caffeine intake regulate microglia reactivity and protect retina against transient ischemic damage. Cell Death Dis. 2017, 8, e3065. [CrossRef]

235. Boia, R.; Ambrosio, A.F.; Santiago, A.R. Therapeutic opportunities for caffeine and A2A receptor antagonists in retinal diseases. Ophthalmic Res. 2016, 55, 212-218. [CrossRef]

236. Tezel, G. TNF-alpha signaling in glaucomatous neurodegeneration. Prog. Brain Res. 2008, 173, $409-421$. [CrossRef]

237. Yuan, L.; Neufeld, A.H. Tumor necrosis factor-alpha: A potentially neurodestructive cytokine produced by glia in the human glaucomatous optic nerve head. Glia 2000, 32, 42-50. [CrossRef] 
238. Roh, M.; Zhang, Y.; Murakami, Y.; Thanos, A.; Lee, S.C.; Vavvas, D.G.; Benowitz, L.I.; Miller, J.W. Etanercept, a widely used inhibitor of tumor necrosis factor-alpha (TNF-alpha), prevents retinal ganglion cell loss in a rat model of glaucoma. PLoS ONE 2012, 7, e40065. [CrossRef]

239. Zhang, Y.; Xu, Y.; Sun, Q.; Xue, S.; Guan, H.; Ji, M. Activation of P2X7R- NLRP3 pathway in Retinal microglia contribute to Retinal Ganglion Cells death in chronic ocular hypertension (COH). Exp. Eye Res. 2019, 188, 107771. [CrossRef]

240. Fernandez-Albarral, J.A.; Ramirez, A.I.; de Hoz, R.; Lopez-Villarin, N.; Salobrar-Garcia, E.; Lopez-Cuenca, I.; Licastro, E.; Inarejos-Garcia, A.M.; Almodovar, P.; Pinazo-Duran, M.D.; et al. Neuroprotective and Anti-Inflammatory Effects of a Hydrophilic Saffron Extract in a Model of Glaucoma. Int. J. Mol. Sci. 2019, 20, 4110. [CrossRef]

241. Howell, G.R.; Macalinao, D.G.; Sousa, G.L.; Walden, M.; Soto, I.; Kneeland, S.C.; Barbay, J.M.; King, B.L.; Marchant, J.K.; Hibbs, M.; et al. Molecular clustering identifies complement and endothelin induction as early events in a mouse model of glaucoma. J. Clin. Investig. 2011, 121, 1429-1444. [CrossRef]

242. Mirzaei, M.; Gupta, V.B.; Chick, J.M.; Greco, T.M.; Wu, Y.; Chitranshi, N.; Wall, R.V.; Hone, E.; Deng, L.; Dheer, Y.; et al. Age-related neurodegenerative disease associated pathways identified in retinal and vitreous proteome from human glaucoma eyes. Sci. Rep. 2017, 7, 12685. [CrossRef]

243. Tezel, G.; Yang, X.; Luo, C.; Kain, A.D.; Powell, D.W.; Kuehn, M.H.; Kaplan, H.J. Oxidative stress and the regulation of complement activation in human glaucoma. Investig. Ophthalmol. Vis. Sci. 2010, 51, 5071-5082. [CrossRef]

244. Tyler, C.M.; Boulanger, L.M. Complement-mediated microglial clearance of developing retinal ganglion cell axons. Neuron 2012, 74, 597-599. [CrossRef]

245. Schafer, D.P.; Lehrman, E.K.; Kautzman, A.G.; Koyama, R.; Mardinly, A.R.; Yamasaki, R.; Ransohoff, R.M.; Greenberg, M.E.; Barres, B.A.; Stevens, B. Microglia sculpt postnatal neural circuits in an activity and complement-dependent manner. Neuron 2012, 74, 691-705. [CrossRef]

246. Rosen, A.M.; Stevens, B. The role of the classical complement cascade in synapse loss during development and glaucoma. Adv. Exp. Med. Biol. 2010, 703, 75-93. [CrossRef]

247. Wang, K.; Peng, B.; Lin, B. Fractalkine receptor regulates microglial neurotoxicity in an experimental mouse glaucoma model. Glia 2014, 62, 1943-1954. [CrossRef]

248. Breen, K.T.; Anderson, S.R.; Steele, M.R.; Calkins, D.J.; Bosco, A.; Vetter, M.L. Loss of fractalkine signaling exacerbates axon transport dysfunction in a chronic model of glaucoma. Front. Neurosci. 2016, 10, 526. [CrossRef]

249. Bosco, A.; Inman, D.M.; Steele, M.R.; Wu, G.; Soto, I.; Marsh-Armstrong, N.; Hubbard, W.C.; Calkins, D.J.; Horner, P.J.; Vetter, M.L. Reduced retina microglial activation and improved optic nerve integrity with minocycline treatment in the DBA/2J mouse model of glaucoma. Investig. Ophthalmol. Vis. Sci. 2008, 49, 1437-1446. [CrossRef]

250. Vecino, E.; Rodriguez, F.D.; Ruzafa, N.; Pereiro, X.; Sharma, S.C. Glia-neuron interactions in the mammalian retina. Prog. Retin. Eye Res. 2016, 51, 1-40. [CrossRef]

251. Ruzafa, N.; Vecino, E. Effect of Muller cells on the survival and neuritogenesis in retinal ganglion cells. Arch. Soc. Esp. Oftalmol. 2015, 90, 522-526. [CrossRef]

252. Ruzafa, N.; Pereiro, X.; Lepper, M.F.; Hauck, S.M.; Vecino, E. A proteomics approach to identify candidate proteins secreted by muller glia that protect ganglion cells in the retina. Proteomics 2018, 18, e1700321. [CrossRef]

253. Bringmann, A.; Pannicke, T.; Biedermann, B.; Francke, M.; Iandiev, I.; Grosche, J.; Wiedemann, P.; Albrecht, J.; Reichenbach, A. Role of retinal glial cells in neurotransmitter uptake and metabolism. Neurochem. Int. 2009, 54, 143-160. [CrossRef]

254. Garcia, M.; Vecino, E. Role of Muller glia in neuroprotection and regeneration in the retina. Histol. Histopathol. 2003, 18, 1205-1218. [CrossRef]

255. Heidinger, V.; Hicks, D.; Sahel, J.; Dreyfus, H. Ability of retinal Muller glial cells to protect neurons against excitotoxicity in vitro depends upon maturation and neuron-glial interactions. Glia 1999, 25, 229-239. [CrossRef]

256. Kawasaki, A.; Otori, Y.; Barnstable, C.J. Muller cell protection of rat retinal ganglion cells from glutamate and nitric oxide neurotoxicity. Investig. Ophthalmol. Vis. Sci. 2000, 41, 3444-3450. 
257. Kitano, S.; Morgan, J.; Caprioli, J. Hypoxic and excitotoxic damage to cultured rat retinal ganglion cells. Exp. Eye Res. 1996, 63, 105-112. [CrossRef]

258. Izumi, Y.; Kirby, C.O.; Benz, A.M.; Olney, J.W.; Zorumski, C.F. Muller cell swelling, glutamate uptake, and excitotoxic neurodegeneration in the isolated rat retina. Glia 1999, 25, 379-389. [CrossRef]

259. Carter-Dawson, L.; Crawford, M.L.; Harwerth, R.S.; Smith, E.L., 3rd; Feldman, R.; Shen, F.F.; Mitchell, C.K.; Whitetree, A. Vitreal glutamate concentration in monkeys with experimental glaucoma. Investig. Ophthalmol. Vis. Sci. 2002, 43, 2633-2637.

260. Biedermann, B.; Bringmann, A.; Franze, K.; Faude, F.; Wiedemann, P.; Reichenbach, A. GABA(A) receptors in Muller glial cells of the human retina. Glia 2004, 46, 302-310. [CrossRef]

261. Hurley, J.B.; Lindsay, K.J.; Du, J. Glucose, lactate, and shuttling of metabolites in vertebrate retinas. J. Neurosci. Res. 2015, 93, 1079-1092. [CrossRef]

262. Matteucci, A.; Gaddini, L.; Villa, M.; Varano, M.; Parravano, M.; Monteleone, V.; Cavallo, F.; Leo, L.; Mallozzi, C.; Malchiodi-Albedi, F.; et al. Neuroprotection by rat Muller glia against high glucose-induced neurodegeneration through a mechanism involving ERK1/2 activation. Exp. Eye Res. 2014, 125, $20-29$. [CrossRef]

263. Vohra, R.; Kolko, M. Neuroprotection of the inner retina: Muller cells and lactate. Neural Regen. Res. 2018, 13, 1741-1742. [CrossRef]

264. Eastlake, K.; Luis, J.; Limb, G.A. Potential of muller glia for retina neuroprotection. Curr. Eye Res. 2020, 45, 339-348. [CrossRef]

265. Reichelt, W.; Stabel-Burow, J.; Pannicke, T.; Weichert, H.; Heinemann, U. The glutathione level of retinal Muller glial cells is dependent on the high-affinity sodium-dependent uptake of glutamate. Neuroscience 1997, 77, 1213-1224. [CrossRef]

266. Harada, T.; Harada, C.; Nakamura, K.; Quah, H.M.; Okumura, A.; Namekata, K.; Saeki, T.; Aihara, M.; Yoshida, H.; Mitani, A.; et al. The potential role of glutamate transporters in the pathogenesis of normal tension glaucoma. J. Clin. Investig. 2007, 117, 1763-1770. [CrossRef]

267. Eichler, W.; Savkovic-Cvijic, H.; Burger, S.; Beck, M.; Schmidt, M.; Wiedemann, P.; Reichenbach, A.; Unterlauft, J.D. Muller cell-derived PEDF mediates neuroprotection via STAT3 activation. Cell. Physiol. Biochem. 2017, 44, 1411-1424. [CrossRef]

268. Taylor, S.; Srinivasan, B.; Wordinger, R.J.; Roque, R.S. Glutamate stimulates neurotrophin expression in cultured Muller cells. Brain Res. Mol. Brain Res. 2003, 111, 189-197. [CrossRef]

269. Harada, T.; Harada, C.; Nakayama, N.; Okuyama, S.; Yoshida, K.; Kohsaka, S.; Matsuda, H.; Wada, K. Modification of glial-neuronal cell interactions prevents photoreceptor apoptosis during light-induced retinal degeneration. Neuron 2000, 26, 533-541. [CrossRef]

270. Eastlake, K.; Banerjee, P.J.; Angbohang, A.; Charteris, D.G.; Khaw, P.T.; Limb, G.A. Muller glia as an important source of cytokines and inflammatory factors present in the gliotic retina during proliferative vitreoretinopathy. Glia 2016, 64, 495-506. [CrossRef]

271. Yoshida, S.; Sotozono, C.; Ikeda, T.; Kinoshita, S. Interleukin-6 (IL-6) production by cytokine-stimulated human Muller cells. Curr. Eye Res. 2001, 22, 341-347. [CrossRef]

272. Busik, J.V.; Mohr, S.; Grant, M.B. Hyperglycemia-induced reactive oxygen species toxicity to endothelial cells is dependent on paracrine mediators. Diabetes 2008, 57, 1952-1965. [CrossRef]

273. Mohr, S.; Xi, X.; Tang, J.; Kern, T.S. Caspase activation in retinas of diabetic and galactosemic mice and diabetic patients. Diabetes 2002, 51, 1172-1179. [CrossRef]

274. Tezel, G.; Wax, M.B. Increased production of tumor necrosis factor-alpha by glial cells exposed to simulated ischemia or elevated hydrostatic pressure induces apoptosis in cocultured retinal ganglion cells. J. Neurosci. Off. J. Soc. Neurosci. 2000, 20, 8693-8700. [CrossRef]

275. Pereiro, X.; Ruzafa, N.; Acera, A.; Fonollosa, A.; Rodriguez, F.D.; Vecino, E. Dexamethasone protects retinal ganglion cells but not Muller glia against hyperglycemia in vitro. PLoS ONE 2018, 13, e0207913. [CrossRef]

276. Kumar, A.; Pandey, R.K.; Miller, L.J.; Singh, P.K.; Kanwar, M. Muller glia in retinal innate immunity: A perspective on their roles in endophthalmitis. Crit. Rev. Immunol. 2013, 33, 119-135. [CrossRef]

277. Zong, H.; Ward, M.; Madden, A.; Yong, P.H.; Limb, G.A.; Curtis, T.M.; Stitt, A.W. Hyperglycaemia-induced pro-inflammatory responses by retinal Muller glia are regulated by the receptor for advanced glycation end-products (RAGE). Diabetologia 2010, 53, 2656-2666. [CrossRef]

278. Bringmann, A.; Wiedemann, P. Muller glial cells in retinal disease. Ophthalmologica 2012, 227, 1-19. [CrossRef] 
279. Greenberg, M.E.; Xu, B.; Lu, B.; Hempstead, B.L. New insights in the biology of BDNF synthesis and release: Implications in CNS function. J. Neurosci. Off. J. Soc. Neurosci. 2009, 29, 12764-12767. [CrossRef]

280. Allen, S.J.; Watson, J.J.; Shoemark, D.K.; Barua, N.U.; Patel, N.K. GDNF, NGF and BDNF as therapeutic options for neurodegeneration. Pharmacol. Ther. 2013, 138, 155-175. [CrossRef]

281. Shruthi, S.; Sumitha, R.; Varghese, A.M.; Ashok, S.; Chandrasekhar Sagar, B.K.; Sathyaprabha, T.N.; Nalini, A.; Kramer, B.W.; Raju, T.R.; Vijayalakshmi, K.; et al. Brain-Derived Neurotrophic Factor Facilitates Functional Recovery from ALS-Cerebral Spinal Fluid-Induced Neurodegenerative Changes in the NSC-34 Motor Neuron Cell Line. Neuro Degener. Dis. 2017, 17, 44-58. [CrossRef]

282. Ferrari, M.P.; Mantelli, F.; Sacchetti, M.; Antonangeli, M.I.; Cattani, F.; D'Anniballe, G.; Sinigaglia, F.; Ruffini, P.A.; Lambiase, A. Safety and pharmacokinetics of escalating doses of human recombinant nerve growth factor eye drops in a double-masked, randomized clinical trial. BioDrugs Clin. Immunother. Biopharm. Gene Ther. 2014, 28, 275-283. [CrossRef]

283. Cantor, L.B. Brimonidine in the treatment of glaucoma and ocular hypertension. Ther. Clin. Risk Manag. 2006, 2, 337-346. [CrossRef]

284. WoldeMussie, E.; Ruiz, G.; Wijono, M.; Wheeler, L.A. Neuroprotection of retinal ganglion cells by brimonidine in rats with laser-induced chronic ocular hypertension. Investig. Ophthalmol. Vis. Sci. 2001, 42, 2849-2855.

285. Grieb, P. Neuroprotective properties of citicoline: Facts, doubts and unresolved issues. CNS Drugs 2014, 28, 185-193. [CrossRef]

286. Parisi, V.; Manni, G.; Colacino, G.; Bucci, M.G. Cytidine-5'-diphosphocholine (citicoline) improves retinal and cortical responses in patients with glaucoma. Ophthalmology 1999, 106, 1126-1134. [CrossRef]

287. Parisi, V.; Oddone, F.; Ziccardi, L.; Roberti, G.; Coppola, G.; Manni, G. Citicoline and retinal ganglion cells: Effects on morphology and function. Curr. Neuropharmacol. 2018, 16, 919-932. [CrossRef]

288. Parisi, V. Electrophysiological assessment of glaucomatous visual dysfunction during treatment with cytidine-5'-diphosphocholine (citicoline): A study of 8 years of follow-up. Doc. Ophthalmol. Adv. Ophthalmol. 2005, 110, 91-102. [CrossRef]

289. Weinreb, R.N.; Liebmann, J.M.; Cioffi, G.A.; Goldberg, I.; Brandt, J.D.; Johnson, C.A.; Zangwill, L.M.; Schneider, S.; Badger, H.; Bejanian, M. Oral memantine for the treatment of glaucoma. Ophthalmology 2018, 125, 1874-1885. [CrossRef]

290. Steigerwalt, R.D., Jr.; Cesarone, M.R.; Pascarella, A.; De Angelis, M.; Nebbioso, M.; Belcaro, G.; Feragalli, B. Ocular and optic nerve ischemia: Recognition and treatment with intravenous prostaglandin E1. Panminerva Med. 2011, 53, 119-124.

291. Rosenthal, R.; Fromm, M. Endothelin antagonism as an active principle for glaucoma therapy. Br. J. Pharmacol. 2011, 162, 806-816. [CrossRef]

292. Wang, J.; Chen, S.; Zhang, X.; Huang, W.; Jonas, J.B. Intravitreal triamcinolone acetonide, retinal microglia and retinal ganglion cell apoptosis in the optic nerve crush model. Acta Ophthalmol. 2016, 94, e305-e311. [CrossRef]

293. Sheng, Y.; Zhu, Y.; Wu, L. Effect of high dosage of methylprednisolone on rat retinal ganglion cell apoptosis after optic nerve crush. Yan Ke Xue Bao Eye Sci. 2004, 20, 181-186.

294. Rath, E.Z.; Hazan, Z.; Adamsky, K.; Solomon, A.; Segal, Z.I.; Levin, L.A. Randomized controlled phase 2a study of RPh201 in previous nonarteritic anterior ischemic optic neuropathy. J. Neuroophthalmol. 2019, 39, 291-298. [CrossRef] [PubMed]

295. Shaheer, M.; Amjad, A.; Saleem, Z. Retinal ganglion cell complex changes after intravitreal bevacizumab for diabetic macular edema. J. Coll. Phys. Surg. Pak. JCPSP 2019, 29, 426-429. [CrossRef] [PubMed]

296. Entezari, M.; Esmaeili, M.; Yaseri, M. A pilot study of the effect of intravenous erythropoetin on improvement of visual function in patients with recent indirect traumatic optic neuropathy. Graefes Arch. Clin. Exp. Ophthalmol. 2014, 252, 1309-1313. [CrossRef]

297. Kashkouli, M.B.; Pakdel, F.; Sanjari, M.S.; Haghighi, A.; Nojomi, M.; Homaee, M.H.; Heirati, A. Erythropoietin: A novel treatment for traumatic optic neuropathy-A pilot study. Graefes Arch. Clin. Exp. Ophthalmol. 2011, 249, 731-736. [CrossRef]

298. Kilic, U.; Kilic, E.; Soliz, J.; Bassetti, C.I.; Gassmann, M.; Hermann, D.M. Erythropoietin protects from axotomy-induced degeneration of retinal ganglion cells by activating ERK-1/-2. FASEB J. Off. Publ. Fed. Am. Soc. Exp. Biol. 2005, 19, 249-251. [CrossRef] 
299. Meyerson, C.; Van Stavern, G.; McClelland, C. Leber hereditary optic neuropathy: Current perspectives. Clin. Ophthalmol. 2015, 9, 1165-1176. [CrossRef]

300. Lyseng-Williamson, K.A. Idebenone: A Review in leber's hereditary optic neuropathy. Drugs 2016, 76, 805-813. [CrossRef]

301. Kim, S.Y.; Shim, M.S.; Kim, K.Y.; Weinreb, R.N.; Wheeler, L.A.; Ju, W.K. Inhibition of cyclophilin D by cyclosporin A promotes retinal ganglion cell survival by preventing mitochondrial alteration in ischemic injury. Cell Death Dis. 2014, 5, e1105. [CrossRef]

302. Medvedev, Z.A. An attempt at a rational classification of theories of ageing. Biol. Rev. Camb. Philos. Soc. 1990, 65, 375-398. [CrossRef]

303. Zeng, H.; Sanes, J.R. Neuronal cell-type classification: Challenges, opportunities and the path forward. Nat. Rev. Neurosci. 2017, 18, 530-546. [CrossRef] [PubMed]

304. Diao, L.; Sun, W.; Deng, Q.; He, S. Development of the mouse retina: Emerging morphological diversity of the ganglion cells. J. Neurobiol. 2004, 61, 236-249. [CrossRef] [PubMed]

305. Fukuda, Y. A three-group classification of rat retinal ganglion cells: Histological and physiological studies. Brain Res. 1977, 119, 327-334. [CrossRef]

306. Sanes, J.R.; Masland, R.H. The types of retinal ganglion cells: Current status and implications for neuronal classification. Ann. Rev. Neurosci. 2015, 38, 221-246. [CrossRef] [PubMed]

307. Langer, K.B.; Ohlemacher, S.K.; Phillips, M.J.; Fligor, C.M.; Jiang, P.; Gamm, D.M.; Meyer, J.S. Retinal ganglion cell diversity and subtype specification from human pluripotent stem cells. Stem Cell Rep. 2018, 10, 1282-1293. [CrossRef]

308. Kay, J.N.; De la Huerta, I.; Kim, I.J.; Zhang, Y.; Yamagata, M.; Chu, M.W.; Meister, M.; Sanes, J.R. Retinal ganglion cells with distinct directional preferences differ in molecular identity, structure, and central projections. J. Neurosci. Off. J. Soc. Neurosci. 2011, 31, 7753-7762. [CrossRef]

309. Yonehara, K.; Shintani, T.; Suzuki, R.; Sakuta, H.; Takeuchi, Y.; Nakamura-Yonehara, K.; Noda, M. Expression of SPIG1 reveals development of a retinal ganglion cell subtype projecting to the medial terminal nucleus in the mouse. PLoS ONE 2008, 3, e1533. [CrossRef]

310. Duan, X.; Qiao, M.; Bei, F.; Kim, I.J.; He, Z.; Sanes, J.R. Subtype-specific regeneration of retinal ganglion cells following axotomy: Effects of osteopontin and mTOR signaling. Neuron 2015, 85, 1244-1256. [CrossRef]

311. Hattar, S.; Liao, H.W.; Takao, M.; Berson, D.M.; Yau, K.W. Melanopsin-containing retinal ganglion cells: Architecture, projections, and intrinsic photosensitivity. Science 2002, 295, 1065-1070. [CrossRef]

312. Mao, C.A.; Li, H.; Zhang, Z.; Kiyama, T.; Panda, S.; Hattar, S.; Ribelayga, C.P.; Mills, S.L.; Wang, S.W. T-box transcription regulator Tbr2 is essential for the formation and maintenance of Opn4/melanopsin-expressing intrinsically photosensitive retinal ganglion cells. J. Neurosci. Off. J. Soc. Neurosci. 2014, 34, 13083-13095. [CrossRef]

313. Volgyi, B.; Chheda, S.; Bloomfield, S.A. Tracer coupling patterns of the ganglion cell subtypes in the mouse retina. J. Comp. Neurol. 2009, 512, 664-687. [CrossRef] [PubMed]

314. Kim, I.J.; Zhang, Y.; Meister, M.; Sanes, J.R. Laminar restriction of retinal ganglion cell dendrites and axons: Subtype-specific developmental patterns revealed with transgenic markers. J. Neurosci. Off. J. Soc. Neurosci. 2010, 30, 1452-1462. [CrossRef] [PubMed]

315. Huberman, A.D.; Manu, M.; Koch, S.M.; Susman, M.W.; Lutz, A.B.; Ullian, E.M.; Baccus, S.A.; Barres, B.A. Architecture and activity-mediated refinement of axonal projections from a mosaic of genetically identified retinal ganglion cells. Neuron 2008, 59, 425-438. [CrossRef] [PubMed]

316. Triplett, J.W.; Wei, W.; Gonzalez, C.; Sweeney, N.T.; Huberman, A.D.; Feller, M.B.; Feldheim, D.A. Dendritic and axonal targeting patterns of a genetically-specified class of retinal ganglion cells that participate in image-forming circuits. Neural Dev. 2014, 9, 2. [CrossRef]

317. Rheaume, B.A.; Jereen, A.; Bolisetty, M.; Sajid, M.S.; Yang, Y.; Renna, K.; Sun, L.; Robson, P.; Trakhtenberg, E.F. Single cell transcriptome profiling of retinal ganglion cells identifies cellular subtypes. Nat. Commun. 2018, 9, 2759. [CrossRef]

318. Ou, Y.; Jo, R.E.; Ullian, E.M.; Wong, R.O.; Della Santina, L. Selective vulnerability of specific retinal ganglion cell types and synapses after transient ocular hypertension. J. Neurosci. Off. J. Soc. Neurosci. 2016, 36, 9240-9252. [CrossRef] [PubMed]

319. Daniel, S.; Clark, A.F.; McDowell, C.M. Subtype-specific response of retinal ganglion cells to optic nerve crush. Cell Death Discov. 2018, 4, 7. [CrossRef] 
320. Cui, Q.; Ren, C.; Sollars, P.J.; Pickard, G.E.; So, K.F. The injury resistant ability of melanopsin-expressing intrinsically photosensitive retinal ganglion cells. Neuroscience 2015, 284, 845-853. [CrossRef]

321. Ruiz-Ederra, J.; Garcia, M.; Hernandez, M.; Urcola, H.; Hernandez-Barbachano, E.; Araiz, J.; Vecino, E. The pig eye as a novel model of glaucoma. Exp. Eye Res. 2005, 81, 561-569. [CrossRef]

322. Christensen, I.; Lu, B.; Yang, N.; Huang, K.; Wang, P.; Tian, N. The susceptibility of retinal ganglion cells to glutamatergic excitotoxicity is type-specific. Front. Neurosci. 2019, 13, 219. [CrossRef]

323. Mayer, C.; Bruehl, C.; Salt, E.L.; Diem, R.; Draguhn, A.; Fairless, R. Selective vulnerability of alphaOFF retinal ganglion cells during onset of autoimmune optic neuritis. Neuroscience 2018, 393, 258-272. [CrossRef] [PubMed]

324. Puyang, Z.; Gong, H.Q.; He, S.G.; Troy, J.B.; Liu, X.; Liang, P.J. Different functional susceptibilities of mouse retinal ganglion cell subtypes to optic nerve crush injury. Exp. Eye Res. 2017, 162, 97-103. [CrossRef] [PubMed]

325. Feng, L.; Zhao, Y.; Yoshida, M.; Chen, H.; Yang, J.F.; Kim, T.S.; Cang, J.; Troy, J.B.; Liu, X. Sustained ocular hypertension induces dendritic degeneration of mouse retinal ganglion cells that depends on cell type and location. Investig. Ophthalmol. Vis. Sci. 2013, 54, 1106-1117. [CrossRef] [PubMed]

326. Vidal-Sanz, M.; Galindo-Romero, C.; Valiente-Soriano, F.J.; Nadal-Nicolas, F.M.; Ortin-Martinez, A.; Rovere, G.; Salinas-Navarro, M.; Lucas-Ruiz, F.; Sanchez-Migallon, M.C.; Sobrado-Calvo, P.; et al. Shared and Differential Retinal Responses against Optic Nerve Injury and Ocular Hypertension. Front. Neurosci. 2017, 11, 235. [CrossRef] [PubMed]

327. La Morgia, C.; Carelli, V.; Carbonelli, M. Melanopsin retinal ganglion cells and pupil: Clinical implications for neuro-ophthalmology. Front. Neurol. 2018, 9, 1047. [CrossRef]

328. VanderWall, K.B.; Lu, B.; Wang, S.; Meyer, J.S. Differential susceptibility of rat retinal ganglion cells following optic nerve crush. bioRxiv 2018, 429282. [CrossRef]

329. Siegert, S.; Scherf, B.G.; Del Punta, K.; Didkovsky, N.; Heintz, N.; Roska, B. Genetic address book for retinal cell types. Nat. Neurosci. 2009, 12, 1197-1204. [CrossRef]

330. Norsworthy, M.W.; Bei, F.; Kawaguchi, R.; Wang, Q.; Tran, N.M.; Li, Y.; Brommer, B.; Zhang, Y.; Wang, C.; Sanes, J.R.; et al. Sox11 Expression Promotes Regeneration of Some Retinal Ganglion Cell Types but Kills Others. Neuron 2017, 94, 1112-1120.e4. [CrossRef]

331. Harada, C.; Kimura, A.; Guo, X.; Namekata, K.; Harada, T. Recent advances in genetically modified animal models of glaucoma and their roles in drug repositioning. Br. J. Ophthalmol. 2019, 103, 161-166. [CrossRef]

332. DeBusk, A.; Moster, M.L. Gene therapy in optic nerve disease. Curr. Opin. Ophthalmol. 2018, 29, $234-238$. [CrossRef]

333. Yang, S.; Ma, S.Q.; Wan, X.; He, H.; Pei, H.; Zhao, M.J.; Chen, C.; Wang, D.W.; Dong, X.Y.; Yuan, J.J.; et al. Long-term outcomes of gene therapy for the treatment of Leber's hereditary optic neuropathy. EBioMedicine 2016, 10, 258-268. [CrossRef] [PubMed]

334. Feuer, W.J.; Schiffman, J.C.; Davis, J.L.; Porciatti, V.; Gonzalez, P.; Koilkonda, R.D.; Yuan, H.; Lalwani, A.; Lam, B.L.; Guy, J. Gene therapy for leber hereditary optic neuropathy: Initial results. Ophthalmology 2016, 123, 558-570. [CrossRef] [PubMed]

335. Wan, X.; Pei, H.; Zhao, M.J.; Yang, S.; Hu, W.K.; He, H.; Ma, S.Q.; Zhang, G.; Dong, X.Y.; Chen, C.; et al. Efficacy and safety of rAAV2-ND4 treatment for leber's hereditary optic neuropathy. Sci. Rep. 2016, 6, 21587. [CrossRef] [PubMed]

336. Suzuki, K.; Tsunekawa, Y.; Hernandez-Benitez, R.; Wu, J.; Zhu, J.; Kim, E.J.; Hatanaka, F.; Yamamoto, M.; Araoka, T.; Li, Z.; et al. In vivo genome editing via CRISPR/Cas9 mediated homology-independent targeted integration. Nature 2016, 540, 144-149. [CrossRef] [PubMed]

337. Jain, A.; Zode, G.; Kasetti, R.B.; Ran, F.A.; Yan, W.; Sharma, T.P.; Bugge, K.; Searby, C.C.; Fingert, J.H.; Zhang, F.; et al. CRISPR-Cas9-based treatment of myocilin-associated glaucoma. Proc. Natl. Acad. Sci. USA 2017, 114, 11199-11204. [CrossRef] [PubMed]

(C) 2020 by the authors. Licensee MDPI, Basel, Switzerland. This article is an open access article distributed under the terms and conditions of the Creative Commons Attribution (CC BY) license (http://creativecommons.org/licenses/by/4.0/). 